\title{
SME Credit Constraints and Access to \\ Informal Credit Markets in Vietnam
}

\begin{abstract}
Purpose - A review of literature has documented that accessing formal credit and other banking services has always been a crucial challenge for small and medium-sized enterprises (SMEs). The alternative, therefore, tends to be informal channels. However, the credit constraint vis-à-vis informal channel link does not appear to be well documented in the literature. This study aims to investigate whether credit constraints significantly affect the probability of accessing informal credit, as well as the credit values of Vietnamese SMEs.
\end{abstract}

Design/methodology/approach - This study uses a trinary approach and correlated random-effects Probit and Tobit techniques to avoid the incidental coefficients problem.

Findings - Our results suggest that relative to unconstrained and partially constrained firms, fully constrained firms tend to be more active in the informal credit markets, shown by their higher probability of informal credit access and larger credit values.

Originality/value - To the best of our knowledge, this is the first study on Vietnam that takes a different approach to credit constraints and examines their impact on informal credit access. Policy implications arise and are discussed.

Keywords Vietnam, Credit constraints, Informal credit, SMEs

Paper type Research paper

JEL classification: $\mathrm{O} 16, \mathrm{O} 53$ 


\section{Introduction}

SMEs have increasingly become an integral and substantial component of private sectors worldwide, including industrialised and emerging economies, in particular (Beck and DemirgucKunt, 2006). In Asia, for instance, SMEs account for 90 percent of all enterprises and create 5080 percent of all jobs (Tambunan, 2008). In Vietnam, SMEs represent 97 percent of total enterprises, contribute 46 percent of GDP, and account for 59 percent of total employment (ADB, 2013). Indeed, this sector has substantially contributed to the development of the national economy through various major socio-economic aspects, including GDP growth, job creation, manufacturing, and poverty reduction (CIEM, 2014). However, like most business enterprises, SMEs also require sustainable access to external credit, without which survival and long-term growth prospects may be seriously jeopardised (Rahaman 2011). Two broad channels of financing have traditionally been available to SMEs: formal and informal financing. The first might include sources such as venture capital, initial public offerings, and formal financial sector loans (e.g., banks) and the second might encompass borrowing from friends, family members, relatives, private moneylenders, and trade creditors.

The literature and anecdotal evidence have suggested that accessing formal credit and other banking services, especially at affordable rates has always been a crucial challenge for SMEs (e.g., Nguyen, Su, and Sharma, 2019; Rahaman, 2011) and the constraints appear much graver than for their larger counterparts (Kuntchev et al., 2012; Schiffer and Weder, 2001). Indeed, approximately 50 percent of SMEs in developing economies report formal credit access as a major constraint (Bouri et al., 2011). The alternative, therefore, for a large number, especially younger and smaller SMEs, appears to be informal channels, making this source a common channel in supporting the financing of SMEs (Mehnaz and Wimpey, 2007). However, the credit constraint vis-à-vis informal channel link does not appear to be very well documented in the literature (e.g., Barslund and Tarp, 2008; Degryse, Lu, and Ongena, 2016; Nguyen and Luu, 2013; Viet Nguyen and Berg, 2014) ${ }^{1}$. How often and to what extent are credit-constrained SMEs really driven and compelled to seek funding from informal markets? And, what might the impeding and facilitating factors be? This paper attempts to fill this gap in the literature, using Vietnam as a case study.

In this paper, deviating from the conventional dichotomous categorisation (constrained and unconstrained), we categorise firms into three groups: fully constrained, partially constrained, and unconstrained firms. Previous studies on credit constraints of firms have often employed the binary approach (constrained and unconstrained) in the context of, for example, the United States

\footnotetext{
${ }^{1}$ Most of earlier studies have analysed the operations of formal and informal credit segments, instead of investigating the connection between formal credit constraints and informal credit access.
} 
(Jappelli, 1990), the United Kingdom (Saridakis, Mole and Hay, 2012), India (Banerjee and Duflo, 2014), China (Poncet, Steingress and Vandenbussche, 2010), Mozambique (Byiers et al., 2010), and Vietnam (Barslund and Tarp, 2008; Rand, 2007; Tran and Santarelli, 2013). Other studies develop the concept by categorising credit constraints into orderly groups. Kuntchev et al. (2012), for example, categorise credit constrained firms into four classes: fully credit constrained, partially credit constrained, "maybe" credit constrained, and non-credit constrained. Bottazzi, Secchi and Tamagni (2014) used three different degrees, including non-financially, mildly financially, and highly financially constrained firms.

In the case of Vietnam, a research by Nguyen and Luu (2013) is the only SME financingchoice study that adopts a non-binary approach. Four unordered categories are considered: formal, informal, both formal and informal, and none of formal and informal. Different from Nguyen and Luu (2013), our research follows the approach by Nguyen, Su, and Sharma (2019) to introduce an ordered three-category credit constraint, in which the partial-constraint category works as a bridge between constraint and no constraint. In this approach, unconstrained firms are those that either applied for loans and had their applications fully approved and had no more credit demands, or those that did not apply for loans because of no credit demand. Partially constrained firms are those applying for loans and having their applications partially approved, or their applications were fully approved and they still had further loan demands. Firms are fully constrained if they applied for loans and had their applications fully rejected, or those that did not apply for loans because of reasons such as high interest rate, inadequate collateral, or difficult process, rather than because of no credit demand. The determination of three groups of credit constraints enables us to avoid loss of valuable information caused by imposing the middle class of constraint onto the fully constrained category.

Our data comes mainly from the Survey of Small and Medium Scale Manufacturing Enterprises (SMEs) in Vietnam from 2005 to 2013. The methods used are the correlated randomeffects Probit and Tobit approaches. Results show that credit constraints significantly influence both the probability of access to informal credit as well as the amounts obtained. Relative to unconstrained and partially constrained firms, fully constrained firms tend to be more active in the informal credit markets, shown by their higher probability of informal credit access and larger credit values. The significant relationship between credit constraints and informal credit access confirms the importance of the informal credit markets in satisfying credit demands of SMEs in Vietnam. In terms of policy implications, our findings suggest that with respect to SMEs' temporary credit demands in Vietnam, a short-term solution might have to be informal credit, especially for credit-constrained firms. However, in the longer term, firms need to be encouraged 
to access more sustainable formal credit, perhaps with appropriate state and local business association support.

The rest of the paper is structured as follows: Section 2 provides the context of formal and informal credit markets in Vietnam; Section 3 presents the literature review; Section 4 outlines data and methods, including data description, variable selection, and econometric approach; Section 5 presents results; and Section 6 highlights the conclusion.

\section{Formal and informal credit markets in Vietnam}

The formal credit markets are dominated by state-owned commercial banks, including the Vietnam Bank for Social Policies (VBSP), the Vietnam Bank for Agriculture and Rural Development (VBARD), the Vietnam Development Bank (VDB), and the Co-operative Bank of Vietnam (CBV). The total assets and outstanding loans of this sector accounts for approximately 70 percent of all financial service providers (World Bank, 2014). Among these, VBSP and VDB are government policy banks that offer a wide range of financial products and services to the poor and other targeted clients at preferential rates. Table I shows that the outstanding credit balance by formal institution has increased substantially during the period 2001-2016.

Table I. Outstanding loans by formal institutions in Vietnam (VND billion)

\begin{tabular}{lccccc}
\hline Institution & 2001 & 2005 & 2010 & 2013 & 2016 \\
\hline Vietnam Bank for Social Policies (VBSP) & 6,194 & 17,305 & 88,806 & 120,417 & 156,033 \\
Vietnam Bank for Agriculture and Rural & 35,342 & 93,000 & 420,420 & 518,780 & 732,360 \\
Development (VBARD) & & & & & \\
Vietnam Development Bank (VDB) & $\ldots$ & 89,096 & 171,095 & 257,490 & 300,383 \\
Co-operative Bank of Vietnam [1] (CBV) & 3,288 & 8,959 & 4,945 & 13,865 & 18,195 \\
Capital Aid Fund for Employment of the & 41 & 145 & 1,592 & 3,123 & 5,666 \\
Poor (CEP) & & & & & \\
\hline
\end{tabular}

Notes: Authors' calculation from annual reports of VBSP, VBARD, VDB, CPCF, and CEP.

The informal credit markets include private moneylenders, relatives and friends and sources such as traditional rural credit associations. While the significance of informal markets has been emphasised in previous empirical studies (Barslund and Tarp, 2008; Duong and Izumida, 2002; Khoi et al., 2013; McMillan and Woodruff, 1999; Tran, Walle and Herwartz, 2018), there is limited information on the informal credit markets in Vietnam, in particular for SMEs. Due to the difficulties in obtaining formal loans, Vietnamese SMEs often consider borrowing money from informal sources, making this source the most useful channel for obtaining financing (Mehnaz and Wimpey, 2007). According to the Central Institute for Economic Management (CIEM, 2014), only 
26 percent of Vietnamese SMEs have access to formal credit. Borrowing from informal sources makes up 80 percent of the total number of SME loan applications.

Table II shows the characteristics of formal and informal credit for SMEs in Vietnam during the period 2005-2013. As the table shows, access to formal credit markets appears to have declined during this period (40 to 26 percent) and access to informal markets increased (29 to 62 percent), peaking at 70 percent in 2009. The number of loans obtained has largely been dominated by informal sources. As well, interest rates and collateral requirements have been lower in the case of informal credit. Regarding credit sources, state-owned commercial banks are "key players" in the formal markets, while private moneylenders, relatives, and friends are the main sources of finance in the informal markets.

Table II. Characteristics of formal and informal credit for SMEs in Vietnam

\begin{tabular}{|c|c|c|c|c|c|}
\hline & 2005 & 2007 & 2009 & 2011 & 2013 \\
\hline Access to formal credit markets (\%) & 39.29 & 36.85 & 37.61 & 29.70 & 25.85 \\
\hline Number of loans obtained ${ }^{a}$ & 715 & 580 & 463 & 310 & 241 \\
\hline Loan amount, average (VND) ${ }^{b}$ & 601,932 & $1,338,289$ & $1,061,398$ & $1,572,649$ & $2,100,894$ \\
\hline Interest rate, average $(\% \text { per month })^{b}$ & 1.21 & 1.03 & 1.07 & 1.67 & 1.20 \\
\hline Collateral required $(\%)^{\mathrm{b}}$ & 82.65 & 89.00 & 91.93 & 93.76 & 94.81 \\
\hline Formal credit sources ${ }^{\mathrm{b}}$ & Pct. & Pct. & Pct. & Pct. & Pct. \\
\hline State-owned commercial banks (SOCBs) & 68.72 & 64.35 & 67.27 & 56.94 & 63.92 \\
\hline Private/joint stock banks & 11.56 & 14.51 & 11.48 & 20.21 & 17.96 \\
\hline Foreign banks & 0.47 & 0.85 & 1.40 & 0.92 & 1.20 \\
\hline Social Policy Bank & 7.39 & 12.91 & 11.28 & 8.85 & 5.84 \\
\hline Development assistance fund (DAF) & 1.42 & 2.13 & 2.99 & 3.57 & 1.20 \\
\hline Targeted programs & 6.35 & 0.43 & 0.60 & - & 0.90 \\
\hline Access to informal credit markets ${ }^{\mathrm{b}}$ & 29.40 & 60.49 & 70.33 & 64.42 & 62.83 \\
\hline Number of loans obtained ${ }^{\text {a }}$ & 562 & 2,001 & 1,587 & 973 & 439 \\
\hline Loan amount, average (VND) ${ }^{\mathrm{b}}$ & 213,040 & 226,634 & 433,033 & 406,524 & 475,254 \\
\hline Interest rate $(\% \text { per month })^{b}$ & 0.92 & 0.82 & 0.79 & 0.97 & 0.62 \\
\hline Collateral required $(\%)^{b}$ & 2.65 & 1.75 & 10.98 & 17.34 & 5.74 \\
\hline Informal credit sources ${ }^{b}$ & Pct. & Pct. & Pct. & Pct. & Pct. \\
\hline Private moneylenders & 44.67 & 9.38 & 8.34 & 7.47 & 5.16 \\
\hline Relatives and friends to owner & 41.32 & 18.32 & 18.68 & 17.06 & 17.55 \\
\hline Enterprises & 11.62 & 4.81 & 2.57 & 1.08 & 2.61 \\
\hline
\end{tabular}

Source: Authors' calculations based on the Survey of Manufacturing SMEs in Vietnam

Notes: ${ }^{\text {a }}$ denotes the long-term loans; ${ }^{\mathrm{b}}$ denotes the most important loan in value terms

\section{Literature review}

A number of earlier studies on access to credit have focused separately on either formal or informal credit (Buyinza and Bbaale, 2013; Cowling, Liu and Zhang, 2016; Lee, Sameen and Cowling, 2015; McPherson and Rous, 2010; Tran and Santarelli, 2013). Others have analysed 
the interaction of formal and informal credit markets (Barslund and Tarp, 2008; Mohieldin and Wright, 2000; Hoang and Otake, 2014; Khoi et al., 2013). For example, Degryse, Lu and Ongena (2016) document the advantages of using formal and informal credit. Interest costs for formal sources tend to be relatively lower because formal credit institutions, in particular commercial banks, specialise in processing hard information, such as credit rating, business plans, financial statements, and transaction lending. In the informal markets, on the other hand, soft information, such as relationship lending and reputation of borrowers, is the primary basis for decision-making. In the same vein, a study by Allen, Qian, and Xie (2018) focuses on a framework that informal financing and formal financing (especially banking capital) are comparable, emphasising that informal financing is a complementary channel when formal credit is limited. Das (2018) analyses credit demands through formal, semiformal, and informal channels, showing that demands on these credit markets are elastic with interest rates.

Relatively, informal credit does have some advantages, such as a less bureaucratic process with high repayment flexibility (Germidis, Kessler and Meghir, 1991). Further, procedures are often less complex and time consuming, resulting in lower transaction costs. These features help explain why informal sources might be attractive for SMEs, in particular micro and smaller firms that are not able to satisfy collateral requirements of formal lenders (Cao, 2014). Still, conditions and costs of informal credit applied to borrowers may vary, depending on specific sources and relationships, such as high rates in the case of moneylenders and trade creditors, but low rates in the case of close friends and family members (Safavian and Wimpey, 2007). Safavian and Wimpey find that compared to formal credit, informal credit appears to have flexible requirements, such as more lenient collateral, low transaction costs, less frequent inspections, and lower demands for bribes. However, because of the limitation of informal credit, borrowing from this sector is relatively more costly than from the formal sources; hence, making the informal sources less desirable for larger firms that wish to finance big projects. Banerjee and Duflo (2005) demonstrate that firms borrow from informal lenders at exorbitant interest rates that range from 30 to 60 percent. Based on a panel dataset of non-financial SMEs in India, De and Singh (2011) estimate the range of interest rates charged in the informal credit markets varies from 50 to 58 percent. Seeking credit from informal sources is preferred by risk-taking owners because informal credit is somewhat unreliable, resulting in an increased risk of bankruptcy (Hoang and Otake, 2014; Safavian and Wimpey, 2007).

Beck, Demirgüç-Kunt and Maksimovic (2008) find that small firms are indeed heavily reliant on internal and informal capital, and less dependent on formal loans compared to larger firms. Due to asymmetric information that causes adverse selection and moral hazard problems, younger firms appear to mobilise finance from informal sources (Akoten, Sawada and Otsuka, 
2006; Pham and Lensink, 2007). Additionally, the literature has highlighted the importance of credit rating of private firms as a signal of their reputation and ability to approach formal or informal financial sources. Frame, Srinivasan and Woosley (2001) and Frame and Woosley (2004) find that better credit scoring positively influences the average size of loans extended to small firms. Zhang (2008), in the case of China, shows that the credit rating experience of private entrepreneurs makes them more likely to borrow formal capital. This finding is affirmed by Cowling, Liu and Zhang (2016) in the case of UK SMEs: commercial banks were highly willing to lend to firms with a low-risk rating or those without any record of financial delinquency.

However, literature is scarcer on the association between formal credit constraints and access to the informal credit markets. Using panel data of UK firms, Atanasova and Wilson (2003) find that firms that are constrained by commercial banks are more likely to use trade credit in the informal markets. Although trade credit is a costly substitute for bank credit, it may help relax bank credit rationing processes, in particular in the case of strict lending conditions and restricted loan size. Beck, Demirgüç-Kunt and Maksimovic (2008) employ data from 3,000 enterprises in 48 countries and show that financing obstacles significantly and positively affect the use of informal finance. The severity of financing obstacles is determined based on responses of firm managers on a rating of how problematic financing is for firm operation and growth [2]. Yet, the extant literature has been limited to providing empirical evidence of the connection between the degree of formal credit constraints and informal credit access. Thus, this research gap is of interest and worthy of further examination. It is suspected that the severity of credit constraints in the formal markets has an effect on the use of informal credit.

A concern when examining the link between informal and formal credit is "endogeneity" (Viet Nguyen and Berg, 2014). As such, the endogeneity issue regarding the participation of constrained firms might initially arise from unobserved characteristics of individual borrowers, such as attitudes to risk, abilities, and business skills. Further, this problem might be caused by the reverse causality between formal and informal credit. Accordingly, credit constrained firms in the formal markets tend to seek informal capital (Madestam, 2014). Conversely, firms using informal credit are more likely to increase their demand for formal credit, thus having higher probability of constraints, which might lead to endogeneity (Khoi et al., 2013). All in all, the presence of endogeneity, if not addressed, may result in biased estimations and misleading interpretations of the participation of constrained firms in the informal credit markets.

Rand (2007) shows that approximately from 14 to 25 percent of SMEs in Vietnam are credit constrained, thus emphasising the important role of the informal credit markets, in particular for fast-growing firms. Cao (2014) analyses determinants of access to informal credit of Vietnamese SMEs. The author finds that firms that are constrained in the formal credit markets 
(those whose applications were denied, those obtaining formal credit but still had further demand, and those having credit demand but did not apply for formal credit) tend to seek capital in the informal markets to satisfy their credit demands and to reduce application costs. In another study of Vietnamese SMEs, Hoang and Otake (2014) show that 90 percent of constrained firms in the formal credit markets rely on capital from the informal markets. The number of firms obtaining informal credit is double the number of firms obtaining formal credit, which helps to explain the significance of the informal markets in SME financing patterns. In light of the foregoing:

H1. In Vietnam, credit-constrained SMEs are more likely to borrow from the informal markets.

H2. More severely constrained firms have a higher probability of using informal credit and obtaining a larger loan size.

\section{Data and methods}

\subsection{Data description}

This study uses data from a field firm-level survey conducted in Vietnam-a Survey of Small and Medium Scale Manufacturing Enterprises, which has been used in previous studies as well (e.g., Rand, 2007; Rand and Torm, 2012; Tran and Santarelli, 2013). The Survey has been a collaboration among the Central Institute for Economic Management, the Institute of Labour Science and Social Affairs (Vietnam), and the University of Copenhagen (Denmark), under the sponsorship of the Danish International Development Agency. The Survey was carried out biennially from 2005 to 2013 in three urban cities (Ha Noi, Hai Phong, and Ho Chi Minh City) and seven rural provinces (Phu Tho, Ha Tay, Nghe An, Quang Nam, Khanh Hoa, Lam Dong, and Long An) [3]. Data were collected from approximately 2,500 registered and non-registered manufacturing SMEs in each round, with a response rate of about 98 percent (see Table A1 in the Appendix).

The population sources included the Established Census and the Industrial Survey. The interviewer visited each enterprise in the selected provinces and met with the owner or manager for face-to-face interviews. Responses were initially verified in the field and were checked more thoroughly at a later date. Information and details from the Survey cover all firm-related issues, including firm characteristics; enterprises growth and dynamics (employment growth and firm turnover); bureaucracy, informality, and informal payments; investment and access to finance; production, technology, and labour productivity; employment; environment; trade and sales structures. The data used in this study are unique and expected to provide a novel insight into the Vietnam private sector. 
Table III presents the accessibility to informal credit by categories of constraints based on our database. The main reasons that firms seek capital from the informal market include more favourable interest rates, more relaxed procedures, more lenient collateral requirements, and flexible repayments among others. In general, 57 percent of SMEs accessed informal credit. Among these, 38.7 percent preferred borrowing from informal sources because of flexible payback conditions, 11.4 percent because of easier procedure, and 9.1 percent because of no collateral requirement. The percentage of unconstrained firms having access to informal credit was about 5 percent lower than those having no access. Less than 1 percent of unconstrained firms had access to informal credit because of inability to obtain formal credit. The main reason for unconstrained firms to have informal credit access arises from the flexibility of repayment, applying to 42 percent. As for constrained firms, partially and fully constrained firms shared relatively similar percentages with 66 percent borrowing from informal sources, in which fully constrained firms had a slightly higher proportion. Nearly 8 percent of fully constrained firms sought informal credit because of their inability to borrow from formal sources, while this percentage of partially constrained firms was 3 percent. In both cases, the majority of constrained firms, either partially or fully, regarded flexible payback conditions as a major attraction of informal credit, followed by no collateral requirement and easier procedures. Table III also shows the test of the equality of the proportions between partially and fully constrained firms. A significant $z$-statistic $(P$-value $=0.000)$ suggests a rejection of the null hypothesis; that is, the proportion of partially constrained firms in the informal credit markets is indeed smaller than their counterparts.

Table III. Access to informal credit

\begin{tabular}{lcccc}
\hline & Full sample & Unconstrained & $\begin{array}{c}\text { Partially } \\
\text { constrained }\end{array}$ & $\begin{array}{c}\text { Fully } \\
\text { constrained }\end{array}$ \\
\hline Total & $6,075(100)$ & $3,006(49.48)$ & $1,216(20.02)$ & $1,853(30.50)$ \\
Non-access to informal credit & $2,611(42.98)$ & $1,570(52.23)$ & $413(33.96)$ & $628(33.89)$ \\
Access to informal credit & $3,464(57.02)$ & $1,436(47.77)$ & $803(66.04)$ & $1,225(66.11)$ \\
$\quad$ Couldn't obtain formal credit & $133(3.84)$ & $14(0.97)$ & $24(2.99)$ & $95(7.76)$ \\
$\quad$ Most favourable interest & $103(2.97)$ & $35(2.44)$ & $17(2.12)$ & $51(4.16)$ \\
$\quad$ Easier procedure & $394(11.37)$ & $111(7.73)$ & $110(13.70)$ & $173(14.12)$ \\
$\quad$ No collateral required & $315(9.09)$ & $92(6.41)$ & $15(14.32)$ & $108(8.82)$ \\
$\quad$ Flexible payback & $1,341(38.71)$ & $604(42.06)$ & $278(34.62)$ & $459(37.47)$ \\
$\quad$ Other & $1,178(34.01)$ & $580(40.39)$ & $259(32.25)$ & $339(27.67)$ \\
\hline Proportion test $(z$-stat) & & \multicolumn{3}{c}{$-10.267^{* * *}$} \\
\hline
\end{tabular}

Source: Authors' calculations based on the Survey of Manufacturing SMEs in Vietnam

Notes: Percentages are in parentheses. $* * *$ indicates significance at 1 percent. The null hypothesis of the proportion test is $\mathrm{H}_{0}$ : the difference between the proportion of partially constrained and fully constrained firms having access to informal credit is greater than zero. 


\subsection{Variables}

Variables used in this study are described in Table IV. As previously mentioned, this study aims to provide understanding on how credit constraints might affect the participation of SMEs in the informal credit markets regarding the probability and the value of loans. As such, the key independent variable is firm credit constraints, constructed from the direct responses of firm representatives. The three-level independent variable enables us to capture the extent to which a firm is credit constrained without relying on accounting information, such as profits and dividends [4]. Other control variables include firm size, age, type, revenue, investment, network size, gender of owner, age of owner, and educational level (Barslund and Tarp, 2008; Imarhiagbe, Saridakis and Mohammed, 2017; Le, 2012; Nguyen and Luu, 2013; Rand, 2007).

Table IV. Description of variables

\begin{tabular}{|c|c|}
\hline Variables & Description \\
\hline \multicolumn{2}{|l|}{ Dependent variables } \\
\hline Informal credit access & $\begin{array}{l}\text { Dummy variable. } 1 \text { if firms borrowed from informal sources (e.g., friends, } \\
\text { family members, moneylenders, etc.) since last survey, } 0 \text { otherwise }\end{array}$ \\
\hline $\begin{array}{l}\text { Informal credit value } \\
(\log .)\end{array}$ & $\begin{array}{l}\text { The natural logarithm of informal liabilities including informal short-term debt } \\
\text { (up to one year) and long-term debt (over a year) in the end of year }\end{array}$ \\
\hline \multicolumn{2}{|l|}{ Independent variables } \\
\hline Credit constraints & $\begin{array}{l}\text { Ordered variable. } 1 \text { for unconstrained firms: those that either applied for loans and } \\
\text { had their applications fully approved and had no more credit demands, or those } \\
\text { that did not apply for loans because of no credit demand; } 2 \text { for partially constrained } \\
\text { firms: those that applied for loans and had their applications partially approved, or } \\
\text { those whose applications were fully approved and they still had further loan } \\
\text { demands; } 3 \text { for fully constrained firms: those that applied for loans and had their } \\
\text { applications fully rejected, or those that did not apply for loans because of other } \\
\text { reasons such as high interest rate, inadequate collateral, or difficult process, rather } \\
\text { than because of no credit demand. }\end{array}$ \\
\hline Firm size (log.) & The natural logarithm of total assets \\
\hline Firm age & $\begin{array}{l}\text { The age of firms expressed in years, calculated as the difference between the } \\
\text { year of survey and the firm's year of establishment }\end{array}$ \\
\hline Firm type & Dummy variable. 1 if firms are household-owned, 0 otherwise \\
\hline Revenue (log.) & The natural logarithm of firm revenue in the end of year \\
\hline Investment & Dummy variable. 1 if firms made investment since last survey, 0 otherwise \\
\hline Network size & The number of business associations that a firm is member of \\
\hline Gender of owner & Dummy variable. 1 if owner is male, 0 if female \\
\hline Age of owner & $\begin{array}{l}\text { The age of owner expressed in years, calculated as the difference between the } \\
\text { year of survey and the owner's year of birth }\end{array}$ \\
\hline Education & $\begin{array}{l}\text { Dummy variable. } 1 \text { if owner graduated from undergraduate or postgraduate } \\
\text { program, } 0 \text { otherwise }\end{array}$ \\
\hline
\end{tabular}




\subsection{Econometric approach}

This study uses random-effects and correlated random-effects Probit and Tobit models to examine relationships between credit constraints and informal credit access. Due to the nature of our dataset, many independent variables are time invariant, implying that they do not or seldom change over time (e.g., firm age that is determined from the establishment year, location where firms are located, gender and educational level of owner, or even ownership structure - such as household businesses or cooperative). Accordingly, the fixed-effects approach is inappropriate because it would eliminate all time-invariant effects from the analysis; in other words, it does not allow the estimation of time-invariant variables (Plümper and Troeger, 2007; Wooldridge, 2010). Hence, random-effect estimations are preferred. The issue of unobserved heterogeneity that arises from variation between and within individuals is addressed by using random-effects and correlated random-effects approaches. Appendix B provides further discussion on endogeneity.

\subsubsection{The probability of access to informal credit}

This study models the relationship between credit constraints and access to informal credit by using the latent variable approach. Let the latent variable $I C_{i t}^{*}$ for firm $i$ at time $t$ denote the unobservable variable of the probability of accessing informal credit and be defined as [5]

$$
I C_{i t}^{*}=C C_{i t} \beta_{1}+X_{i t}^{\prime} \beta_{2}+c_{i}+u_{i t}
$$

where, $C C_{i t}$ is the categorical variable of interest, representing firm credit constraints and taking three values (1: unconstrained, 2: partially constrained, and 3: fully constrained). $\beta_{1}$ captures the coefficients of credit constraints, $\beta_{2}$ captures the vector of coefficients associated with $X_{i t}, c_{i}$ denotes the individual specific unobserved effect, and $u_{i t}$ is a normally distributed disturbance with zero mean and variance $\sigma_{u}^{2}, u_{i t} \sim \operatorname{IN}\left(0, \sigma_{u}^{2}\right)$.

Let $I C_{i t}$ be the binary observed variable of informal credit. The dependent variable in the random-effects Probit model is

$$
I C_{i t}=1\left[I C_{i t}^{*}>0\right]
$$

The distribution of $I C_{i t}$ given $C C_{i t}$ and $X_{i t}$ and the individual specific unobserved effect $c_{i}$ can be expressed as follows

$$
P\left[I C_{i t} \mid C C_{i t}, X_{i t}, c_{i}\right]=\Phi\left(C C_{i t} \beta_{1}+X_{i t}^{\prime} \beta_{2}+c_{i}\right)
$$

\subsubsection{Value of informal credit}

To examine the relationship between credit constraints and the value of informal credit that a firm can obtain, this paper uses the random-effects Tobit and correlated random-effects Tobit models. 
Let the latent variable $V I C_{i t}^{*}$ denote the unobservable variable of the value of informal credit for firm $i$ at time $t$ and be defined as

$$
\begin{aligned}
& V I C_{i t}^{*}=C C_{i t} \beta_{1}+X_{i t}^{\prime} \beta_{2}+c_{i}+u_{i t} \\
& V I C_{i t}=\max \left(0, V I C_{i t}^{*}\right)
\end{aligned}
$$

where $V I C_{i t}$ is the dependent observed variable of informal credit value. The distribution of $V I C_{i t}$ given $C C_{i t}, X_{i t}$, and $c_{i}$ is expressed as

$$
\begin{aligned}
P\left[V I C_{i t} \mid C C_{i t}, X_{i t}, c_{i}\right] & =\Phi\left[\left(C C_{i t} \beta_{1}+X_{i t}^{\prime} \beta_{2}+c_{i}\right) / \sigma\right] \times \\
& \left(C C_{i t} \beta_{1}+X_{i t}^{\prime} \beta_{2}+c_{i}\right)+\sigma \times \emptyset\left(C C_{i t} \beta_{1}+X_{i t}^{\prime} \beta_{2}+c_{i}\right)
\end{aligned}
$$

where $\Phi($.$) and \varnothing($.$) denote the cumulative distribution function and density of the standard$ normal distribution, respectively.

\subsubsection{Correlated random effects (CRE) approach}

Using the random-effects approach requires an assumption $c_{i} \mid C C_{i}, X_{i} \sim N\left(0, \sigma_{c}^{2}\right)$ that is valid only under restrictive assumptions. Fixed-effects analysis might be considered; however, estimating the parameter of interest using fixed-effects Probit/Tobit analysis that treats the unobserved effects $\left(c_{i}\right)$ as parameter to be estimated is subject to incidental coefficients problem (Wooldridge, 2009). For non-linear models, the CRE approach is preferred to avoid the incidental coefficients problem (at the cost of restricting conditional heterogeneity distributions) [6].

It is assumed that $E\left(u_{i t} \mid C C_{i t}, X_{i t}, c_{i}\right)=0$ to ensure the exogeneity assumptions on the independent variables (conditional on the unobserved effect). $c_{i}$ denotes the individual specific unobserved effect and is treated as a random effect, therefore $\operatorname{Cov}\left(C C_{i t}, c_{i}\right)=0$ and $\operatorname{Cov}\left(X_{i t}, c_{i}\right)=0, \quad t=1, \ldots, T ; c_{i}$ is decomposed as

$$
c_{i}=\omega+\overline{C C_{\imath}} \tau_{1}+\bar{X}_{\imath} \tau_{2}+a_{i}
$$

where $E\left(a_{i} \mid C C_{i}, X_{i}\right)=0$. From equations (1), (4), and (7), we have

$$
\begin{aligned}
& I C_{i t}^{*}=C C_{i t} \beta_{1}+X_{i t}^{\prime} \beta_{2}+\omega+\overline{C C_{\imath}} \tau_{1}+\bar{X}_{\imath} \tau_{2}+a_{i}+u_{i t} \\
& V I C_{i t}^{*}=C C_{i t} \beta_{1}+X_{i t}^{\prime} \beta_{2}+\omega+\overline{C C_{\imath}} \tau_{1}+\bar{X}_{\imath} \tau_{2}+a_{i}+u_{i t}
\end{aligned}
$$

where $\overline{C C_{l}}=T^{-1} \sum_{r=1}^{T} C C_{i r}$ and $\bar{X}_{l}=T^{-1} \sum_{r=1}^{T} X_{i r}$ are the vectors of time averages.

The strict exogeneity assumption gives

$$
E\left(I C_{i t}^{*} \mid C C_{i t}, X_{i t}, \overline{C C_{l}}, \bar{X}_{l}\right)=C C_{i t} \beta_{1}+X_{i t}^{\prime} \beta_{2}+\omega+\overline{C C_{l}} \tau_{1}+\bar{X}_{\imath} \tau_{2}
$$


Based on (10), a Hausman-type test is conducted by testing the null hypothesis $H_{0}: \tau_{j}=0$ $(j=1,2)$. If the null hypothesis cannot be rejected, RE is advantageous over CRE; otherwise, the CRE approach is more appropriate.

\section{Results}

\subsection{Descriptive statistics}

Table V presents descriptive statistics by groups of credit constraints (unconstrained firms, partially constrained firms, and fully constrained firms) that have access to informal credit. Relative to firms without access to informal credit, those with access tend to be better networked and with slightly higher incomes. Further, these firms tend to have more investment. They are slightly larger and younger as well as less household-owned. This early indication is consistent with Nguyen and Luu's (2013) research that shows a negative correlation between owner's age and the informal credit accessibility. Accordingly, older owners are more risk-averse; hence, they tend to rely on formal credit and retained earnings rather than on informal loans.

Table V. Descriptive statistics

\begin{tabular}{|c|c|c|c|c|c|c|c|c|}
\hline & \multicolumn{4}{|c|}{$\begin{array}{l}\text { Full sample } \\
\text { (1) }\end{array}$} & \multicolumn{2}{|c|}{$\begin{array}{l}\text { AIC firms } \\
\text { (2) }\end{array}$} & \multicolumn{2}{|c|}{$\begin{array}{l}\text { NAIC firms } \\
\text { (3) }\end{array}$} \\
\hline & Mean & S.D. & Min & Max & Mean & S.D. & Mean & S.D. \\
\hline Credit constraints & 1.810 & 0.874 & 1.000 & 3.000 & 1.939 & 0.874 & 1.639 & 0.844 \\
\hline Firm size (log.) & 13.650 & 1.824 & 4.595 & 19.567 & 13.923 & 1.824 & 13.288 & 1.760 \\
\hline Firm age & 15.236 & 10.123 & 1.000 & 75.000 & 14.777 & 9.422 & 15.844 & 10.955 \\
\hline Firm type $($ Household $=1)$ & 0.716 & 0.451 & 0.000 & 1.000 & 0.656 & 0.475 & 0.796 & 0.403 \\
\hline Revenue (log.) & 13.327 & 1.937 & 0.000 & 22.836 & 13.690 & 1.880 & 12.844 & 1.906 \\
\hline Investment $($ Yes $=1)$ & 0.543 & 0.498 & 0.000 & 1.000 & 0.627 & 0.484 & 0.432 & 0.496 \\
\hline Network size & 31.962 & 35.900 & 0.000 & 717.000 & 35.260 & 41.449 & 27.585 & 26.198 \\
\hline Gender $($ Male = 1) & 0.669 & 0.471 & 0.000 & 1.000 & 0.663 & 0.473 & 0.678 & 0.467 \\
\hline Owner's age & 46.509 & 10.420 & 17.000 & 94.000 & 45.855 & 10.243 & 47.377 & 10.590 \\
\hline Education & 0.250 & 0.433 & 0.000 & 1.000 & 0.279 & 0.448 & 0.212 & 0.409 \\
\hline \multirow[t]{4}{*}{ Number of observations } & 6,075 & & & & 3,464 & & 2,611 & \\
\hline & {$[100]$} & & & & [57.02] & & [42.98] & \\
\hline & \multicolumn{2}{|c|}{$\begin{array}{l}\text { Full sample } \\
\text { (A) }\end{array}$} & \multicolumn{2}{|c|}{$\begin{array}{l}\text { UC firms } \\
\text { (B) }\end{array}$} & \multicolumn{2}{|l|}{$\begin{array}{l}\text { PC firms } \\
\text { (C) }\end{array}$} & \multicolumn{2}{|l|}{$\begin{array}{l}\text { FC firms } \\
\text { (D) }\end{array}$} \\
\hline & Mean & S.D. & $\mathrm{Me}$ & S.D. & Mean & S.D. & Mean & S.D. \\
\hline Inf. cred. access $($ Yes $=1)$ & 0.570 & 0.495 & $\overline{0.4}$ & 0.499 & 0.660 & 0.474 & 0.661 & 0.473 \\
\hline Inf. cred. value (log.) & 3.670 & 5.198 & 2.6 & 4.566 & 4.383 & 5.682 & 4.878 & 5.483 \\
\hline \multirow[t]{2}{*}{ Number of observations } & \multirow{2}{*}{\multicolumn{2}{|c|}{$\begin{array}{l}6,075 \\
{[100]}\end{array}$}} & \multirow{2}{*}{\multicolumn{2}{|c|}{$\begin{array}{c}3,006 \\
{[49.48]}\end{array}$}} & \multirow{2}{*}{\multicolumn{2}{|c|}{$\begin{array}{c}1,216 \\
{[20.02]}\end{array}$}} & \multirow{2}{*}{\multicolumn{2}{|c|}{$\begin{array}{c}1,853 \\
{[30.50]}\end{array}$}} \\
\hline & & & & & & & & \\
\hline Mean of inf. cred. value & & & \multicolumn{2}{|c|}{$\begin{array}{c}P C \text { vs. } U C \\
\text { (E) }\end{array}$} & \multicolumn{2}{|c|}{$\begin{array}{c}F C v s . U C \\
(\mathrm{~F})\end{array}$} & \multicolumn{2}{|l|}{$\begin{array}{c}F C \text { vs. } P C \\
(\mathrm{G})\end{array}$} \\
\hline
\end{tabular}




\begin{tabular}{lccc}
\hline Difference & 1.747 & 2.243 & 0.495 \\
$t$-stats & $10.464^{* * *}$ & $15.383^{* * *}$ & $2.413^{* * *}$ \\
Number of observations & 4,222 & 4,859 & 3,069 \\
\hline
\end{tabular}

Notes: Percentages are in brackets. AIC and NAIC stand for access to informal credit and non-access to informal credit, respectively. UC, PC, and FC stand for unconstrained, partially constrained, and fully constrained, respectively. $* * *$ indicates significance at 1 percent. $t$-stats are reported from ttest with equal variances. The null hypothesis is $\mathrm{H}_{0}$ : Difference $<0$.

In column A, 57 percent of firms in the full sample have access to informal credit. The average value of informal credit is around 200 million VND (3.670 in logs). Columns B, C, and D show that partially and fully constrained firms tend to borrow more from informal credit sources, with 66 percent of such firms having informal credit access. This number is lower, at 47.8 percent, for unconstrained firms. Generally, all firms tend to rely to some extent on informal credit regardless of their level of constraint. Partially and fully constrained firms obtain 1.6- to 1.8-times higher value of credit compared to unconstrained firms. Between these two categories, fully constrained firms use more informal capital than partially constrained, which can be a signal that fully constrained firms are likely to borrow more from informal markets. Apparently, once firms become credit constrained due to the adverse impact of their experience when a loan application was rejected, they may never re-apply for formal funding (Imarhiagbe, Saridakis and Mohammed, 2017). Hence, the informal markets become the more preferred alternative for these firms.

Table $\mathrm{V}$ also shows the equality test of the means of informal credit value among groups: the partially constrained versus the unconstrained, the fully constrained versus the unconstrained, as well as the fully constrained and the partially constrained. In columns $\mathrm{E}$ and $\mathrm{F}$, the significant $t$-stats $(P$ value $=0.000)$ indicate a rejection of the null hypothesis that the difference of means of informal credit value between partially or fully constrained firms versus unconstrained firms is smaller than zero. This implies that the fully constrained and the partially constrained firms have higher value of informal credit than their peers. Similarly, based on a significant $t$-stat shown in column $\mathrm{G}$, we reject the null hypothesis that the difference between fully constrained firms and partially constrained firms regarding means of informal credit value is smaller than zero. This suggests that more severe constrained firms tend to borrow more money in the informal credit markets.

\subsection{Empirical results}

\subsubsection{Credit constraints and the probability of informal credit access}

Table VI reports results from the Probit model with RE and CRE, as described in the method section. A Hausman test is employed to compare the suitability of RE and CRE. The significance $\chi^{2}$ statistics of Hausman test $(P$-value $=0.000)$ shows a rejection of the null hypothesis if the RE specification is appropriate, suggesting that CRE is highly preferred. Thus, our study focuses on CRE results. The estimated results from the CRE approach (column 1) show that credit constraints significantly influence access to informal credit. Constrained firms, in general, have a higher probability of accessing informal credit than their counterparts. Results from the marginal effects show that 
partially and fully constrained firms are more likely to access informal credit by 8.6 and 13.5 percent respectively than unconstrained firms (column 3). This is in line with Karaivanov and Kessler (2018) who show that borrowers with a lower chance of accessing bank loans, or a higher probability of being credit constrained, are more likely to seek more informal loans.

The estimations from the RE Probit (column 4) follow a similar pattern to those reported in the CRE approach. The likelihood of credit-constrained firms accessing informal credit increases from 0.262 to 0.417 (column 1) and from 0.319 to 0.466 (column 4 ) when the degree of constraint rises from partial to full, suggesting that the fully constrained firms may be more active in informal markets. The coefficients of full constraint are positive in both columns 1 and 4 with a higher magnitude than those of partial constraint, implying a high level of participation of the fully constrained group in the informal credit market. Column 6 shows that relative to unconstrained firms, partially constrained firms have a 10.6 percent higher chance of borrowing from the informal markets, while fully constrained firms have 15.3 percent higher chance of accessing informal credit.

The output of pairwise comparisons - post-estimated of CRE-between two groups of credit constrained firms is also presented in Table VI. Accordingly, the expected difference in probability of access to informal credit between fully constrained firms and partially constrained firms is 0.155 and significant, implying that FC firms are significantly more likely to have informal credit access than PC firms. In other words, the more severely constrained, the higher probability of participating in the informal markets. The post-estimations after RE regarding the pairwise comparisons among constraint groups yield similar significant and positive results of the association between constraints and informal credit access.

We find the relationship between credit constraints and informal credit access to be consistent with the findings of Beck, Demirgüç-Kunt and Maksimovic (2008) and Cao (2014). For fully constrained firms (those unable to access formal credit at all), informal credit turns out to be among their preferred alternatives. The informal credit market in Vietnam somewhat acts as a substitute for formal credit because it has been well developed enough to mitigate the pressure from formal credit constraints (Tran and Santarelli, 2013). As expected, firms that failed to obtain credit from the formal credit markets, especially severely constrained firms, are more motivated to borrow from the informal segment.

Table VI. Credit constraints and the probability of informal credit access 


\begin{tabular}{|c|c|c|c|c|c|c|}
\hline \multirow[t]{3}{*}{ Variables } & \multirow{2}{*}{\multicolumn{3}{|c|}{$\begin{array}{l}\text { Correlated random-effects (CRE) } \\
\text { Probit }\end{array}$}} & \multirow{2}{*}{\multicolumn{3}{|c|}{ Random-effects (RE) Probit }} \\
\hline & & & & & & \\
\hline & $\begin{array}{c}\text { Coef. } \\
{[1]}\end{array}$ & $\begin{array}{l}\text { S.E. } \\
{[2]}\end{array}$ & $\begin{array}{c}\text { M.E. } \\
{[3]}\end{array}$ & $\begin{array}{c}\text { Coef. } \\
{[4]}\end{array}$ & $\begin{array}{l}\text { S.E. } \\
{[5]}\end{array}$ & $\begin{array}{c}\text { M.E. } \\
{[6]}\end{array}$ \\
\hline \multicolumn{7}{|l|}{ Credit constrained } \\
\hline PC vs. UC & $0.262 * * *$ & $(0.054)$ & $0.086^{* * *}$ & $0.319 * * *$ & $(0.052)$ & $0.106^{* * *}$ \\
\hline FC vs. UC & $0.417 * * *$ & $(0.048)$ & $0.135 * * *$ & $0.466 * * *$ & $(0.042)$ & $0.153 * * *$ \\
\hline Firm size (log.) & $-0.049 * *$ & $(0.023)$ & $-0.016^{* *}$ & -0.005 & $(0.016)$ & -0.002 \\
\hline Firm age & 0.0001 & $(0.003)$ & 0.000 & $-0.003 *$ & $(0.002)$ & $-0.001 *$ \\
\hline Firm type $($ Household $=1)$ & 0.039 & $(0.106)$ & 0.013 & $-0.180^{* * *}$ & $(0.054)$ & $-0.058 * * *$ \\
\hline Revenue (log.) & $0.075^{* * *}$ & $(0.016)$ & $0.024 * * *$ & $0.083 * * *$ & $(0.013)$ & $0.027 * * *$ \\
\hline Investment $($ Yes $=1)$ & $0.412 * * *$ & $(0.046)$ & $0.132 * * *$ & $0.499 * * *$ & $(0.040)$ & $0.161 * * *$ \\
\hline Network size & $0.001 *$ & $(0.001)$ & 0.000 & $0.002 * * *$ & $(0.001)$ & $0.001 * * *$ \\
\hline Gender $($ Male $=1)$ & -0.070 & $(0.061)$ & -0.022 & 0.010 & $(0.041)$ & 0.003 \\
\hline Owner's age & 0.002 & $(0.003)$ & 0.001 & $-0.008 * * *$ & $(0.002)$ & $-0.003 * * *$ \\
\hline Education & $-0.236 * * *$ & $(0.058)$ & $-0.075 * * *$ & $-0.192 * * *$ & $(0.047)$ & $-0.062 * * *$ \\
\hline Constant & -0.446 & $(0.374)$ & & -0.284 & $(0.278)$ & \\
\hline Year effects & Yes & & Yes & Yes & & \\
\hline Location effects & Yes & & Yes & Yes & & \\
\hline Mundlak correction & Yes & & Yes & No & & \\
\hline Hausman Joint test & $55.03 * * *$ & & & $\ldots$ & & \\
\hline Pairwise comparisons & Contrast & S.E. & & Contrast & S.E. & \\
\hline FC vs. PC & $0.155^{* * *}$ & $(0.058)$ & & $0.147 * * *$ & $(0.057)$ & \\
\hline
\end{tabular}

Notes: Dependent variable is informal credit access. ${ }^{*}, * *$, and $* * *$ indicate significance at 10 percent, 5 percent, and 1 percent, respectively. Standard errors are in parentheses. Marginal effects (M.E.) are reported in columns 3 and 6. UC, PC, and FC stand for unconstrained, partially constrained, and fully constrained, respectively. Number of observations (clusters) is $6,075(1,215)$.

Our findings also reveal that firm and owner characteristics are important in the borrowing decisions, as suggested by Das (2018). From the CRE approach, firm size has a negative and significant effect on informal credit access (column 1), suggesting that smaller firms are more likely to access informal credit. The finding is consistent with Beck, Demirgüç-Kunt and Maksimovic (2008) who find that small firms are more likely to rely on informal credit sources. Regarding revenue, both CRE and RE approaches yield positive effect on the likelihood of access to informal credit, consistent with Rand (2007) and Nguyen and Luu (2013) that high revenue increases demand for more capital. As argued by Allen, Qian, and Xie (2018), informal financing might be better used for new investment and working capital, thus boosting firms' sales growth. We find that firms engaging in investment are more likely to use informal credit by 13.2 percent than those without investment, which is consistent with Viet Nguyen and Berg (2014) who show that approximately 30 percent of informal credit flows to investment and production.

In addition, a significant and positive coefficient of network size suggests that firms with larger network size tend to engage more in the informal markets, consistent with Safavian and Wimpey (2007) and Straub (2005). Concerning owner characteristics, it appears that gender is 
not a significant factor. The coefficients of education in both columns are negative and significant, consistent with Biggs, Raturi and Srivastava (2002), suggesting that educated owners are less likely to participate in the informal credit markets because they typically prefer borrowing from formal sources or self-funding. This is in line with the argument by Lee, Sameen and Cowling (2015) that firms run by qualified entrepreneurs might rely on their own financial resources.

In general, the above variables that are significant in CRE are also significant in RE, except firm size. As for the remaining variables, including firm age, firm type, and owner's age, the results show that they significantly and negatively affect the probability to access informal credit when applying RE approach, but insignificantly in the case of CRE. Column 4 shows that older firms have a lower probability of participating in the informal credit markets, consistent with Rand (2007) and Le (2012) regarding firm life-cycle and its financing policy. Further, the negative coefficient of household demonstrates that the household ownership structure reduces the likelihood of firms having informal credit access because household firms have lower demands for external credit than non-household firms (Bigsten et al., 2003; Rand, 2007).

\subsubsection{Credit constraints and informal credit value}

Results from Tobit models with RE and CRE are reported in Table VII. The significance $\chi^{2}$ statistics of Hausman test $(P$-value $=0.000)$ suggest that CRE is more appropriate than RE. The CRE approach yields positive results - the credit values/amounts obtained by partially and fully constrained firms are higher than for unconstrained firms (column 1). Results from marginal effects show that compared to unconstrained firms, the fully constrained have higher credit values by approximate 1.5 times (column 3). Interestingly, the coefficient of partially constrained firms is insignificant when CRE is considered. Column 4 shows that partially and fully constrained firms obtain larger credit values than unconstrained firms and the estimated coefficients are significant in both categories. In terms of magnitude, as presented in column 6, credit values obtained by the partially and the fully constrained are 0.4 and 1.8-time greater than those used by unconstrained firms, correspondingly. This is also consistent with the $t$-test results shown in Table VI regarding the difference of means of informal credit values among three groups.

The CRE approach yields significant and positive impacts of revenue, investment, and network size on informal credit value (column 1). Consistent with those shown in Table VI, results in Table VII show that more profitable firms tend to borrow more from informal sources and obtain a higher value of informal credit because high-revenue firms have higher credit demands for their business operations, consistent with Nguyen and Luu (2013) and Rand (2007). Further, the positive relationship between investments and informal credit implies that firms making investments obtain larger credit value than unconstrained firms by 1.6 times (column 3 ). 
Similar outcomes are found with RE. In terms of networking, CRE estimated results show that firms engaged in networking tend to obtain the higher values of informal credit, which is consistent with previous studies (Le, Venkatesh, and Nguyen, 2006; Nguyen and Luu, 2013; Safavian and Wimpey, 2007; Straub, 2005). No significant relationship between networking and informal credit value is found when applying RE approach (column 4).

The output of pairwise comparisons after CRE between fully constrained firms and partially constrained firms is also shown in Table VII. As reported, the former has a higher expected difference in probability of access to informal credit than the latter by 3.127 (significant at 1 percent). Consistently, RE post-estimation yields a similar output: a positive and significant difference in informal credit value between fully and partially constrained firms. All in all, more severely constrained firms in the formal markets use larger-sized loans in terms of value in the informal markets.

Table VII. Credit constraints and informal credit value

\begin{tabular}{|c|c|c|c|c|c|c|}
\hline \multirow[t]{3}{*}{ Variables } & \multirow{2}{*}{\multicolumn{3}{|c|}{$\begin{array}{l}\text { Correlated random-effects (CRE) } \\
\text { Tobit }\end{array}$}} & \multirow{2}{*}{\multicolumn{3}{|c|}{ Random-effects (RE) Tobit }} \\
\hline & & & & & & \\
\hline & $\begin{array}{c}\text { Coef. } \\
{[1]}\end{array}$ & $\begin{array}{l}\text { S.E. } \\
{[2]}\end{array}$ & $\begin{array}{c}\text { M.E. } \\
{[3]}\end{array}$ & $\begin{array}{c}\text { Coef. } \\
{[4]}\end{array}$ & $\begin{array}{c}\text { S.E. } \\
{[5]} \\
\end{array}$ & $\begin{array}{l}\text { M.E. } \\
{[6]}\end{array}$ \\
\hline \multicolumn{7}{|l|}{ Credit constrained } \\
\hline PC vs. UC & 0.563 & $(0.501)$ & 0.197 & $1.138^{* *}$ & $(0.490)$ & $0.395^{* *}$ \\
\hline FC vs. UC & $3.690 * * *$ & $(0.461)$ & $1.475 * * *$ & $4.570 * * *$ & $(0.407)$ & $1.834 * * *$ \\
\hline Firm size (log.) & 0.123 & $(0.229)$ & 0.047 & $0.395 * *$ & $(0.155)$ & $0.151 * *$ \\
\hline Firm age & -0.013 & $(0.031)$ & -0.005 & -0.020 & $(0.020)$ & -0.008 \\
\hline Firm type $($ Household $=1)$ & 0.841 & $(1.025)$ & 0.321 & $-1.503 * * *$ & $(0.502)$ & $-0.574 * * *$ \\
\hline Revenue (log.) & $0.500 * * *$ & $(0.162)$ & $0.191 * * *$ & $0.605 * * *$ & $(0.135)$ & $0.231 * * *$ \\
\hline Investment $($ Yes $=1)$ & $4.112 * * *$ & $(0.452)$ & $1.572 * * *$ & $4.812 * * *$ & $(0.398)$ & $1.838 * * *$ \\
\hline Network size & $0.010^{*}$ & $(0.006)$ & $0.004^{*}$ & 0.008 & $(0.005)$ & 0.003 \\
\hline Gender $($ Male $=1)$ & -0.553 & $(0.586)$ & -0.212 & -0.087 & $(0.381)$ & -0.033 \\
\hline Owner's age & 0.014 & $(0.031)$ & 0.005 & $-0.045^{* *}$ & $(0.018)$ & $-0.017 * *$ \\
\hline Education & -0.605 & $(0.544)$ & -0.231 & -0.607 & $(0.447)$ & -0.232 \\
\hline Constant & $-15.215 * * *$ & $(3.387)$ & & $-12.797 * * *$ & $(2.618)$ & \\
\hline Year effects & Yes & & & Yes & & \\
\hline Location effects & Yes & & & Yes & & \\
\hline Mundlak correction & Yes & & & No & & \\
\hline Hausman Joint test & $37.04 * * *$ & & & $\cdots$ & & \\
\hline Pairwise comparisons & Contrast & S.E. & & Contrast & S.E. & \\
\hline FC vs. PC & $3.127 * * *$ & $(0.524)$ & & $3.432 * * *$ & $(0.510)$ & \\
\hline
\end{tabular}

Notes: Dependent variable is informal credit value. *,**, and *** indicate significance at 10 percent, 5 percent, and 1 percent, respectively. Standard errors are in parentheses. Marginal effects (M.E.) are reported in columns 3 and 6. UC, PC, and FC stand for unconstrained, partially constrained, and fully constrained, respectively. Number of observations (clusters) is $6,075(1,215)$. 
Other variables, including firm size, firm type, and owner's age are significantly associated with informal credit value only in the case of RE estimation. For example, consistent with Barslund and Tarp (2008) and Biggs, Raturi, and Srivastava (2002), our study finds a significantly positive impact of firm size on the credit value (given firms obtained a loan). Firm type negatively affects the value of informal credit that firms borrow, suggesting that household firms rely less on informal credit as found by Rand (2007). The effect of firm age on informal credit value is found to be insignificant. Regarding owner characteristics, the age of owners significantly and negatively affects the size of informal loans, implying that older owners tend to use less formal credit than younger owners in terms of both probability and loan size. The coefficients of gender and education are negative in both CRE and RE approaches but insignificant.

\subsubsection{Robustness checks}

In this section, robustness checks are conducted to examine the overall effect of credit constraint on the participation of Vietnamese SMEs in the informal credit markets. Table VIII presents results of robustness checks when credit constraint is considered under the binary approach, in which firms are categorised into constrained and unconstrained groups. The robustness check results are mostly consistent with our results reported in Tables VI and VII. Accordingly, credit constraint has a significant and positive relationship with informal credit access in terms of probability and value in both CRE and RE estimations. Overall, those being constrained in the formal markets are more likely to seek capital in the informal markets and have larger loan size. Results from the Hausman Join test reported in Table VIII show significance $\chi^{2}$ statistics $(P$-values $=0.000$ ), confirming the preference of CRE over RE. Overall, the robustness check estimations affirm the positive association between credit constraint and informal credit access.

Table VIII. Binary credit constraint and informal credit access

\begin{tabular}{|c|c|c|c|c|}
\hline \multirow[t]{3}{*}{ Variables } & \multicolumn{2}{|c|}{$\begin{array}{l}\text { Probability of informal credit } \\
\text { access }\end{array}$} & \multicolumn{2}{|c|}{ Value of informal credit } \\
\hline & $\mathrm{CRE}$ & $\overline{\mathrm{RE}}$ & CRE & $\mathrm{RE}$ \\
\hline & (1) & (2) & (3) & (4) \\
\hline Credit constrained $(\mathrm{Yes}=1)$ & $0.355 * * *$ & $0.415 * * *$ & $2.353 * * *$ & $3.363 * * *$ \\
\hline
\end{tabular}




\begin{tabular}{lcccc}
\hline & $(0.041)$ & $(0.037)$ & $(0.404)$ & $(0.366)$ \\
Firm size (log.) & $-0.051^{* *}$ & -0.008 & 0.090 & $0.311^{* *}$ \\
Firm age & $(0.023)$ & $(0.016)$ & $(0.230)$ & $(0.156)$ \\
& 0.000 & $-0.003^{*}$ & -0.012 & -0.017 \\
Firm type (Household =1) & $(0.003)$ & $(0.002)$ & $(0.031)$ & $(0.020)$ \\
& 0.040 & $0.175^{* * *}$ & 0.862 & $-1.405^{* * *}$ \\
Revenue (log.) & $(0.106)$ & $(0.054)$ & $(1.030)$ & $(0.505)$ \\
Investment (Yes $=1)$ & $0.074^{* * *}$ & $0.081^{* * *}$ & $0.466^{* * *}$ & $0.539^{* * *}$ \\
& $(0.016)$ & $(0.013)$ & $(0.162)$ & $(0.134)$ \\
Network size & $0.399^{* * *}$ & $0.481^{* * *}$ & $3.851^{* * *}$ & $4.397^{* * *}$ \\
& $(0.045)$ & $(0.040)$ & $(0.452)$ & $(0.394)$ \\
Gender (Male $=1)$ & 0.001 & $0.002^{* * *}$ & $0.011^{*}$ & 0.008 \\
& $(0.001)$ & $(0.001)$ & $(0.006)$ & $(0.005)$ \\
Owner's age & -0.069 & 0.013 & -0.545 & -0.008 \\
& $(0.061)$ & $(0.041)$ & $(0.589)$ & $(0.383)$ \\
Education & 0.002 & $-0.008^{* * *}$ & 0.015 & $-0.043^{* *}$ \\
Constant & $(0.003)$ & $(0.002)$ & $(0.031)$ & $(0.018)$ \\
& $-0.239^{* * *}$ & $-0.194^{* * *}$ & -0.701 & -0.685 \\
Year effects & $(0.058)$ & $(0.047)$ & $(0.546)$ & $(0.450)$ \\
Location effects & -0.392 & -0.189 & $-14.156^{* * *}$ & $-10.241^{* * *}$ \\
Mundlak correction & $(0.373)$ & $(0.275)$ & $(3.398)$ & $(2.602)$ \\
Hausman Joint test & Yes & Yes & Yes & Yes \\
\hline
\end{tabular}

Notes: $* * *$, and $* * *$ indicate significance at 10 percent, 5 percent, and 1 percent, respectively. Standard errors are in parentheses. Number of observations (clusters) is 6,075 $(1,215)$.

\section{Conclusion}

While they make up a large part of the private sector, create sizeable employment opportunities and contribute significantly to economic growth and development, SMEs are known to be constantly credit constrained - that is, from the formal financial sector. Informal channels thus appear to be the alternative and even main source of credit for many SMEs. However, the SME credit constraint vis-à-vis informal channel link does not appear to be very well documented in the literature. Taking Vietnam as an example, and data from the Survey of SMEs between 2005 and 2013, this study endeavours to fill this gap in the literature.

Our study takes a slightly different approach than the standard in defining credit constraint: rather than grouping firms into only the constrained and the unconstrained, this study adopts a third group as well— partially constrained (e.g., a trinary rather than a binary approach). The correlated random-effects Probit and Tobit approaches are used to avoid the incidental coefficients problem. Results show that constrained firms are more likely to access informal credit markets and obtain 
larger loans. Also, firm and ownership characteristics are important in influencing access to informal credit markets. More established firms, household-owned businesses, and those with older owners and better educated individuals tend to rely less on informal credit and have smaller loan requirements than their counterparts. On the other hand, firms with larger revenue and investment portfolios are more likely to access informal credit and obtain larger credit values.

In Vietnam, the informal credit segment appears to be a common source of financing for SMEs, in particular constrained firms; however, this is not a sustainable source. Thus, policy initiatives may be targeted to enable firms to have better access to formal credit markets. Two key points may be noted. First, SMEs use informal credit in the short run to meet their temporary financing demands. At this stage, it may be useful for them to have support and guidance from local governments and business associations - in particular the Vietnam Association of Small Medium Enterprises - on using their own capital and borrowed funds more effectively, which may help improve operations and performances and thus better satisfy formal lending requirements. Second, in encouraging SMEs to borrow more from the formal markets, the government might find it useful to work with the formal sector - in particular commercial banks - in making interest rates more competitive and affordable, reducing processing time, relaxing collateral conditions and bureaucracy, among others.

Due to data limitations, our study is limited to credit constraints and informal credit-related issues from the demand side. Further research might consider the supply-side perspectives. Our study has also focused on manufacturing SMEs, so future studies may consider, data permitting, credit-related issues of SMEs in other sectors, such as services and retails. Also, this study has emphasised the relationship between credit constraints and informal credit access. Future studies might look into the impacts of credit constraints and informal credit access on firm performance and growth. In the meantime, our study provides new and useful insights and has policy implications.

\section{Notes}

1. The Co-operative Bank of Vietnam has been transformed from the Central People's Credit Fund since 2013.

2. See, for example, Lee, Sameen and Cowling (2015).

3. Regardless of a merger into Ha Noi since 2008, Ha Tay has still been listed as a separate province to ensure the consistency of the sample over years and make it comparable to previous surveys.

4. See, for example, Beck, Demirgüç-Kunt, and Maksimovic (2008).

5. See, for example, Anastasopoulos et al. (2012), Greene (2004).

6. The use of CRE estimation is proposed by Mundlak (1978) and relaxed by Chamberlain (1980, 1982) to produce widely used estimators as those by fixed effects in a linear model. 


\section{Acknowledgement}

We are grateful to constructive comments and suggestions of the editor and two anonymous referees. All remaining errors are our own.

\section{ORCID}

Lan Archer https://orcid.org/0000-0003-3121-0337

\section{Appendix}

\section{Appendix A: Sample size}

[Insert Table A1 here]

\section{Appendix B: Endogeneity issue}

\section{Econometric strategy}

As indicated, endogeneity regarding the participation of formal, credit-constrained firms in the informal markets may arise from individual unobserved characteristics of borrowers and the reverse causality between formal and informal credit. A two-stage approach is proposed to address the potential endogeneity problem, in which (a) a reduced-form equation of credit constraints is considered in the first stage to capture the individual unobserved characteristics in the residuals (Equation (B1)), and (b) a structural equation in the second stage to estimate the causal parameter and the endogenous bias caused by the unobserved characteristics of firms in the reduced-form equation (Equation B2). Afterwards, our study performs a Durbin-Wu-Hausman test of endogeneity to check the presence of endogeneity, or in other words, if credit constraint is endogenous.

The reduced-form equation is given as

$$
C C_{i t}^{*}=\varphi\left\{C L U R_{i t} Y_{1}+X_{i t}^{\prime} \Upsilon_{2}+\text { Error }\right\}
$$

where, $C C_{i t}^{*}$ represents credit constraints - either partial or full—of firm $i$ at time $t$. $X_{i t}$ is observable time varying and time invariant vector of characteristics of firms and owners. $C L U R_{i t}$ is an instrumental variable that takes 1 if firms hold the Certificate of Land Use Right and 0 otherwise.

The structural equation is given as

$$
I C_{i t}^{*}=\varphi\left\{C C_{i t} \delta_{1}+\operatorname{Res}_{i t} \delta_{2}+X_{i t}^{\prime} \delta_{3}+\text { Error }\right\}
$$


where $I C_{i t}^{*}$ denotes the unobservable variable of informal credit access of firm $i$ at time $t . R_{e s}$ is residuals generated in the reduced form and included in the structural equation. $\delta_{2}$ captures the coefficient of $\operatorname{Res}_{i t}$ in the structural equation.

The Durbin-Wu-Hausman test for endogeneity is then conducted by testing $H_{0}: \delta_{2}=0$. If the null hypothesis cannot be rejected, there is no sign of endogeneity; otherwise, credit constraint is endogenous. The test is reported in Table B1, showing a non-rejection of the null hypothesis. It suggests that credit constraint is exogenous in our study.

\section{Results from the two-stage approach}

The variable of Certificate of Land Use Right (CLUR) is used as an instrument in the reducedform equation as it is expected to be correlated with credit constraints and uncorrelated with the informal credit access. In Vietnam, CLUR has been used as collateral (Rand, 2007); hence firms holding CLUR tend to secure loans and be less credit constrained than those without CLUR. In other words, formal credit institutions, in particular commercial banks, prefer lending those with CLUR. In contrast, lending decisions on the informal credit markets mostly rely on trustworthiness rather than collateral (Turvey and Kong, 2010). Therefore, our variable of CLUR, which represents collateral, is expected not to correlate with informal credit and be a valid instrument for credit constraints. Indeed, results in Table B1 show a significant and negative relationship between CLUR and firms' credit constraints (Panel 1), suggesting that firms possessing CLUR are less likely to be credit constrained, either partially or fully, than their peers. Panel 2 shows no significant evidence on the correlation between PC or FC residuals and informal credit access. The Durbin-Wu-Hausman test of endogeneity with insignificant $\chi^{2}$ implies that we cannot reject the null hypothesis of no sign of endogeneity, or that credit constraint is not an endogenous variable in this study.

[Insert Table B1 here]

\section{References}

Akoten, J. E., Sawada, Y. and Otsuka, K. (2006), "The determinants of credit access and its impacts on micro and small enterprises: The case of garment producers in Kenya", Economic Development and Cultural Change, Vol. 54 No.4, pp. 927-944.

Allen, F., Qian, M. and Xie, J. (2018), "Understanding informal financing", Journal of Financial Intermediation, In Press.

Anastasopoulos, P. C., Mannering, F. L., Shankar, V. N. and Haddock, J. E. (2012), "A study of factors affecting highway accident rates using the random-parameters Tobit model", Accident Analysis and Prevention, Vol. 45, pp. 628-633.

Atanasova, C. V. and Wilson, N. (2003), "Bank borrowing constraints and the demand for trade credit: Evidence from panel data”, Managerial and Decision Economics, Vol. 24 No. 6-7, pp. 503-514. 
Banerjee, A. V. and Duflo, E. (2005), "Growth theory through the lens of development economics", Handbook of Economic Growth, Vol. 1, pp. 473-552.

Banerjee, A. V. and Duflo, E. (2014), "Do firms want to borrow more? Testing credit constraints using a directed lending program", Review of Economic Studies, Vol. 81 No. 2, pp. 572-607.

Barslund, M. and Tarp, F. (2008), "Formal and informal rural credit in four provinces of Vietnam", The Journal of Development Studies, Vol. 44 No. 4, pp. 485-503.

Beck, T. and Demirguc-Kunt, A. (2006), "Small and medium-size enterprises: Access to finance as a growth constraint", Journal of Banking and Finance, Vol. 30 No. 11, pp. 2931-2943.

Beck, T., Demirgüç-Kunt, A. and Maksimovic, V. (2008), "Financing patterns around the world: Are small firms different?", Journal of Financial Economics, Vol. 89 No. 3, pp. 467-487.

Biggs, T., Raturi, M. and Srivastava, P. (2002), "Ethnic networks and access to credit: Evidence from the manufacturing sector in Kenya", Journal of Economic Behaviour and Organization, Vol. 49 No. 4, pp. 473-486.

Bigsten, A., Collier, P., Dercon, S., Fafchamps, M., Gauthier, B., Gunning, J. W., ... and Teal, F. (2003), "Credit constraints in manufacturing enterprises in Africa", Journal of African Economies, Vol. 12 No. 1, pp. 104-125.

Bottazzi, G., Secchi, A. and Tamagni, F. (2014), "Financial constraints and firm dynamics", Small Business Economics, Vol. 42 No. 1, pp. 99-116.

Bouri, A., Breij, M., Diop, M., Kempner, R., Klinger, B. and Stevenson, K. (2011), "Report on support to SMEs in developing countries through financial intermediaries", Dalberg, the United States of America.

Buyinza, F. and Bbaale, E. (2013), "Access to credit and the effect of credit constraints on the performance of manufacturing firms in the East African region: Micro analysis", International Journal of Economics and Finance, Vol. 5 No. 10, pp. 85-99.

Byiers, B., Rand, J., Tarp, F. and Bentzen, J. (2010), "Credit demand in Mozambican manufacturing", Journal of International Development, Vol. 22 No. 1, pp. 37-55.

Cao, T. K. N. (2014), "Why do small and medium enterprises need to access informal credit? The case of Vietnam", International Finance and Banking, Vol. 1 No. 2, pp. 1-17.

Chamberlain, G. (1980), "Analysis of covariance with qualitative data", Review of Economic Studies, Vol. 47 , pp. 225-238.

Chamberlain, G. (1982), "Multivariate regression models for panel data", Journal of Econometrics, Vol. 18 No. 1, pp. 5-46.

CIEM (Central Institute for Economic Management) (2014), "Characteristics of the Vietnamese business environment: Evidence from the SME survey in 2013", Hanoi, Vietnam.

Cowling, M., Liu, W. and Zhang, N. (2016), "Access to bank finance for UK SMEs in the wake of the recent financial crisis", International Journal of Entrepreneurial Behaviour \& Research, Vol. 22 No. 6, pp. 903-932.

Das, T. (2018), "Estimation of rural credit demand: a study of Lower Brahmaputra valley of Assam", International Journal of Emerging Markets, Vol. 13 No. 6, pp. 1855-1875.

De, S. and Singh, M. (2011), "Credit rationing in informal markets: The case of small firms in India", Working Paper, available at https://cafin.ucsc.edu/research/2014 wkshp/De.pdf

Degryse, H., Lu, L. and Ongena, S. (2016), "Informal or formal financing? Evidence on the co-funding of Chinese firms", Journal of Financial Intermediation, Vol. 27, pp. 31-50.

Dinh, H. T. (2014), "Light manufacturing in Vietnam: Creating jobs and prosperity in a middle-income economy", World Bank Publications.

Duong, P. B. and Izumida, Y. (2002), "Rural development finance in Vietnam: A microeconometric analysis of household surveys", World Development, Vol. 30 No. 2, pp. 319-335.

Frame, W. S., Srinivasan, A. and Woosley, L. (2001), "The effect of credit scoring on small-business lending", Journal of Money, Credit and Banking, pp. 813-825.

Frame, W. S. and Woosley, L. (2004), "Credit scoring and the availability of small business credit in lowand moderate-income areas", Financial Review, Vol. 39 No. 1, pp. 35-54.

Germidis, D. A., Kessler, D. and Meghir, R. (1991), "Financial systems and development: What role for the formal and informal financial sectors?", OECD.

Greene, W. (2004), "Fixed effects and bias due to the incidental parameters problem in the Tobit model", Econometric Reviews, Vol. 23 No. 2, pp. 125-147. 
Hansen, H., Rand, J. and Tarp, F. (2009), "Enterprise growth and survival in Vietnam: Does government support matter?", The Journal of Development Studies, Vol. 45 No. 7, pp. 1048-1069.

Hoang, N. A. and Otake, T. (2014), "Credit participation and credit source selection of Vietnam small and medium enterprises", The South East Asian Journal of Management, pp. 104-128.

Imarhiagbe, B. O., Saridakis, G. and Mohammed, A. M. (2017), "Do bank credit rejection and financial education affect financial self-confidence?", International Journal of Entrepreneurial Behavior \& Research, Vol. 23 No. 6, pp. 1033-1051.

Jappelli, T. (1990), "Who is credit constrained in the US economy?", The Quarterly Journal of Economics, Vol. 105 No. 1, pp. 219-234.

Karaivanov, A. and Kessler, A. (2018), "(Dis) advantages of informal loans-Theory and evidence", European Economic Review, Vol. 102, pp. 100-128.

Khoi, P. D., Gan, C., Nartea, G. V. and Cohen, D. A. (2013), "Formal and informal rural credit in the Mekong River Delta of Vietnam: Interaction and accessibility", Journal of Asian Economics, Vol. 26, pp. 1-13.

Kuntchev, V., Ramalho, R., Rodríguez-Meza, J. and Yang, J. S. (2012), "What have we learned from the Enterprise Surveys regarding access to finance by SMEs?", Enterprise Analysis Unit of the Finance and Private Sector Development, The World Bank Group.

Le, P. N. M. (2012), "What determines the access to credit by SMEs?: A case study in Vietnam", Journal of Management Research, Vol. 4 No. 4, pp. 90-115.

Le, N. T., Venkatesh, S. and Nguyen, T. V. (2006), "Getting bank financing: A study of Vietnamese private firms", Asia Pacific Journal of Management, Vol. 23 No. 2, pp. 209-227.

Lee, N., Sameen, H. and Cowling, M. (2015), "Access to finance for innovative SMEs since the financial crisis", Research Policy, Vol. 44 No. 2, pp. 370-380.

Madestam, A. (2014), "Informal finance: A theory of moneylenders", Journal of Development Economics, Vol. 107, pp. 157-174.

McMillan, J. and Woodruff, C. (1999), "Interfirm relationships and informal credit in Vietnam", The Quarterly Journal of Economics, Vol. 114 No. 4, pp. 1285-1320.

McPherson, M. A. and Rous, J. J. (2010), “Access to finance and small enterprise growth: Evidence from East Java”, The Journal of Developing Areas, Vol. 43 No. 2, pp. 159-172.

Mehnaz, S. and Wimpey, J. (2007), "When do enterprises prefer informal credit?", World Bank Policy Research Working Paper, No. 4435.

Mohieldin, M. S. and Wright, P. W. (2000), "Formal and informal credit markets in Egypt", Economic Development and Cultural Change, Vol. 48 No. 3, pp. 657-670.

Mundlak, Y. (1978), "On the pooling of time series and cross section data", Econometrica: Journal of the Econometric Society, pp. 69-85.

Nguyen, N. and Luu, N. T. H. (2013), "Determinants of financing pattern and access to formal-informal credit: The case of small and medium sized enterprises in Viet Nam", Journal of Management Research, Vol. 5 No. 2, pp. 240-259.

Nguyen, L. T., Su, J. J. and Sharma, P. (2019), "SME credit constraints in Asia's rising economic star: fresh empirical evidence from Vietnam", Applied Economics, pp. 1-14.

Pham, T. T. T. and Lensink, R. (2007), "Lending policies of informal, formal and semiformal lenders", Economics of Transition, Vol. 15 No. 2, pp. 181-209.

Plümper, T. and Troeger, V. E. (2007), "Efficient estimation of time-invariant and rarely changing variables in finite sample panel analyses with unit fixed effects", Political Analysis, Vol. 15 No. 2, pp. 124-139.

Poncet, S., Steingress, W. and Vandenbussche, H. (2010), "Financial constraints in China: Firm-level evidence", China Economic Review, Vol. 21 No. 3, pp. 411-422.

Rahaman, M. M. (2011), "Access to financing and firm growth", Journal of Banking and Finance, Vol. 35 No. 3, pp. 709-723.

Rand, J. (2007), "Credit constraints and determinants of the cost of capital in Vietnamese manufacturing", Small Business Economics, Vol. 29 No. 1, pp. 1-13.

Rand, J., and Torm, N. (2012), "The benefits of formalization: Evidence from Vietnamese manufacturing SMEs", World Development, Vol. 40 No. 5, pp. 983-998. 
Safavian, M. and Wimpey, J. (2007), “When do enterprises prefer informal credit?", World Bank Policy Research Working Paper Series.

Saridakis, G., Mole, K. and Hay, G. (2013), "Liquidity constraints in the first year of trading and firm performance", International Small Business Journal, Vol. 31 No. 5, pp. 520-535.

Schiffer, M. and Weder, B. (2001), "Firm size and the business environment: Worldwide survey results", World Bank Publications, Vol. 43.

Straub, S. (2005), "Informal sector: The credit market channel", Journal of Development Economics, Vol. 78 No. 2, pp. 299-321.

Tambunan, T. (2008), "Development of SME in ASEAN with reference to Indonesia and Thailand", Chulalongkorn Journal of Economics, Vol. 20 No. 1, pp. 53-83.

Tran, H. T. and Santarelli, E. (2013), "Capital constraints and the performance of entrepreneurial firms in Vietnam", Industrial and Corporate Change, Vol. 23 No. 3, pp. 827-864.

Tran, V. T., Walle, Y. M. and Herwartz, H. (2018), "Local financial development and household welfare in Vietnam: Evidence from a panel survey", The Journal of Development Studies, Vol. 54 No. 4, pp. 619-640.

Turvey, C. G. and Kong, R. (2010), "Informal lending amongst friends and relatives: can microcredit compete in rural China?", China Economic Review, Vol. 21 No. 4, pp. 544-556.

Viet Nguyen, C. and Berg, M. (2014), "Informal credit, usury, or support? A case study for Vietnam", The Developing Economies, Vol. 52 No. 2, pp. 154-178.

Wooldridge, J. (2009), "New developments in econometrics lecture 6: Nonlinear panel data models", Cemmap Lectures, University College London, http://www. cemmap. ac. uk/resources/imbens wooldridge/slides, 6

Wooldridge, J. (2010), "Econometric analysis of cross section and panel data”, MIT press.

World Bank. (2014), "Vietnam - financial sector assessment”, Financial Sector Assessment Program (FSAP), Washington, DC: World Bank. Retrieved from http://documents.worldbank.org/curated/en/216401468329363389/Vietnam-Financial-sector-assessment

World Bank (2016), "Vietnam 2035: Toward prosperity, creativity, equity, and democracy", Washington, DC: World Bank. doi:10.1596/978-1-4648-0824-1.

Zhang, G. (2008), "The choice of formal or informal finance: Evidence from Chengdu, China", China Economic Review, Vol. 19 No. 4, pp. 659-678. 


\section{List of tables}

Table I. Outstanding loans by formal institutions in Vietnam (VND billion)

\begin{tabular}{lccccc}
\hline Institution & 2001 & 2005 & 2010 & 2013 & 2016 \\
\hline Vietnam Bank for Social Policies (VBSP) & 6,194 & 17,305 & 88,806 & 120,417 & 156,033 \\
Vietnam Bank for Agriculture and Rural & 35,342 & 93,000 & 420,420 & 518,780 & 732,360 \\
Development (VBARD) & & & & & \\
Vietnam Development Bank (VDB) & $\ldots$ & 89,096 & 171,095 & 257,490 & 300,383 \\
Co-operative Bank of Vietnam [1] (CBV) & 3,288 & 8,959 & 4,945 & 13,865 & 18,195 \\
Capital Aid Fund for Employment of the & 41 & 145 & 1,592 & 3,123 & 5,666 \\
Poor (CEP) & & & & & \\
\hline
\end{tabular}

Notes: Authors' calculation from annual reports of VBSP, VBARD, VDB, CPCF, and CEP.

Table II. Characteristics of formal and informal credit for SMEs in Vietnam

\begin{tabular}{|c|c|c|c|c|c|}
\hline & 2005 & 2007 & 2009 & 2011 & 2013 \\
\hline Access to formal credit markets (pct.) & 39.29 & 36.85 & 37.61 & 29.70 & 25.85 \\
\hline Number of loans obtained ${ }^{a}$ & 715 & 580 & 463 & 310 & 241 \\
\hline Loan amount, average (VND) ${ }^{\mathrm{b}}$ & 601,932 & $1,338,289$ & $1,061,398$ & $1,572,649$ & $2,100,894$ \\
\hline Interest rate, average (pct. per month) ${ }^{b}$ & 1.21 & 1.03 & 1.07 & 1.67 & 1.20 \\
\hline Collateral required (pct.) $)^{b}$ & 82.65 & 89.00 & 91.93 & 93.76 & 94.81 \\
\hline Formal credit sources $^{\mathrm{b}}$ & Pct. & Pct. & Pct. & Pct. & Pct. \\
\hline State-owned commercial banks (SOCBs) & 68.72 & 64.35 & 67.27 & 56.94 & 63.92 \\
\hline Private/joint stock banks & 11.56 & 14.51 & 11.48 & 20.21 & 17.96 \\
\hline Foreign banks & 0.47 & 0.85 & 1.40 & 0.92 & 1.20 \\
\hline Social Policy Bank & 7.39 & 12.91 & 11.28 & 8.85 & 5.84 \\
\hline Development assistance fund (DAF) & 1.42 & 2.13 & 2.99 & 3.57 & 1.20 \\
\hline Targeted programs & 6.35 & 0.43 & 0.60 & - & 0.90 \\
\hline Access to informal credit markets ${ }^{\mathrm{b}}$ & 29.40 & 60.49 & 70.33 & 64.42 & 62.83 \\
\hline Number of loans obtained ${ }^{a}$ & 562 & 2,001 & 1,587 & 973 & 439 \\
\hline Loan amount, average (VND) ${ }^{b}$ & 213,040 & 226,634 & 433,033 & 406,524 & 475,254 \\
\hline Interest rate (pct. per month) ${ }^{b}$ & 0.92 & 0.82 & 0.79 & 0.97 & 0.62 \\
\hline Collateral required (pct.) ${ }^{\mathrm{b}}$ & 2.65 & 1.75 & 10.98 & 17.34 & 5.74 \\
\hline Informal credit sources ${ }^{\mathrm{b}}$ & Pct. & Pct. & Pct. & Pct. & Pct. \\
\hline Private moneylenders & 44.67 & 9.38 & 8.34 & 7.47 & 5.16 \\
\hline Relatives and friends to owner & 41.32 & 18.32 & 18.68 & 17.06 & 17.55 \\
\hline Enterprises & 11.62 & 4.81 & 2.57 & 1.08 & 2.61 \\
\hline
\end{tabular}

Source: Authors' calculations based on the Survey of Manufacturing SMEs in Vietnam

Notes: ${ }^{\text {a }}$ denotes the long-term loans; ${ }^{\mathrm{b}}$ denotes the most important loan in value terms 
Table III. Access to informal credit

\begin{tabular}{lcccc}
\hline & Full sample & Unconstrained & $\begin{array}{c}\text { Partially } \\
\text { constrained }\end{array}$ & $\begin{array}{c}\text { Fully } \\
\text { constrained }\end{array}$ \\
\hline Total & $6,075(100)$ & $3,006(49.48)$ & $1,216(20.02)$ & $1,853(30.50)$ \\
Non-access to informal credit & $2,611(42.98)$ & $1,570(52.23)$ & $413(33.96)$ & $628(33.89)$ \\
Access to informal credit & $3,464(57.02)$ & $1,436(47.77)$ & $803(66.04)$ & $1,225(66.11)$ \\
$\quad$ Couldn't obtain formal credit & $133(3.84)$ & $14(0.97)$ & $24(2.99)$ & $95(7.76)$ \\
$\quad$ Most favourable interest & $103(2.97)$ & $35(2.44)$ & $17(2.12)$ & $51(4.16)$ \\
$\quad$ Easier procedure & $394(11.37)$ & $111(7.73)$ & $110(13.70)$ & $173(14.12)$ \\
$\quad$ No collateral required & $315(9.09)$ & $92(6.41)$ & $15(14.32)$ & $108(8.82)$ \\
$\quad$ Flexible payback & $1,341(38.71)$ & $604(42.06)$ & $278(34.62)$ & $459(37.47)$ \\
$\quad$ Other & $1,178(34.01)$ & $580(40.39)$ & $259(32.25)$ & $339(27.67)$ \\
\hline Proportion test (z-stat) & & \multicolumn{3}{c}{$-10.267^{* * *}$} \\
\hline
\end{tabular}

Source: Authors' calculations based on the Survey of Manufacturing SMEs in Vietnam

Notes: Percentages are in parentheses. *** indicates significance at 1 percent. The null hypothesis of the proportion test is $\mathrm{H}_{0}$ : the difference between the proportion of partially constrained and fully constrained firms having access to informal credit is greater than zero.

Table IV. Description of variables

\begin{tabular}{ll}
\hline Variables & Description \\
\hline $\begin{array}{l}\text { Dependent variables } \\
\text { Informal credit access }\end{array}$ & $\begin{array}{l}\text { Dummy variable. } 1 \text { if firms borrowed from informal sources (e.g., friends, } \\
\text { family members, moneylenders, etc.) since last survey, 0 otherwise }\end{array}$ \\
$\begin{array}{l}\text { Informal credit value } \\
\text { (log.) }\end{array}$ & $\begin{array}{l}\text { The natural logarithm of informal liabilities including informal short-term debt } \\
\text { Independent variables }\end{array}$ \\
Credit constraints & $\begin{array}{l}\text { Ordered variable. } 1 \text { for unconstrained firms: those that either applied for loans and } \\
\text { had their applications fully approved and had no more credit demands, or those } \\
\text { that did not apply for loans because of no credit demand; } 2 \text { for partially constrained }\end{array}$ \\
& $\begin{array}{l}\text { firms: those that applied for loans and had their applications partially approved, or } \\
\text { those whose applications were fully approved and they still had further loan }\end{array}$ \\
& $\begin{array}{l}\text { demands; } 3 \text { for fully constrained firms: those that applied for loans and had their } \\
\text { applications fully rejected, or those that did not apply for loans because of other }\end{array}$ \\
& reasons such as high interest rate, inadequate collateral, or difficult process, rather \\
than because of no credit demand.
\end{tabular}


Table V. Descriptive statistics

\begin{tabular}{|c|c|c|c|c|c|c|c|c|}
\hline & \multicolumn{4}{|c|}{$\begin{array}{l}\text { Full sample } \\
(1)\end{array}$} & \multicolumn{2}{|c|}{$\begin{array}{l}\text { AIC firms } \\
\text { (2) }\end{array}$} & \multicolumn{2}{|c|}{$\begin{array}{l}\text { NAIC firms } \\
\text { (3) }\end{array}$} \\
\hline & Mean & S.D. & Min & Max & Mean & S.D. & Mean & S.D. \\
\hline Credit constraints & 1.810 & 0.874 & 1.000 & 3.000 & 1.939 & 0.874 & 1.639 & 0.844 \\
\hline Firm size (log.) & 13.650 & 1.824 & 4.595 & 19.567 & 13.923 & 1.824 & 13.288 & 1.760 \\
\hline Firm age & 15.236 & 10.123 & 1.000 & 75.000 & 14.777 & 9.422 & 15.844 & 10.955 \\
\hline Firm type $($ Household $=1)$ & 0.716 & 0.451 & 0.000 & 1.000 & 0.656 & 0.475 & 0.796 & 0.403 \\
\hline Revenue (log.) & 13.327 & 1.937 & 0.000 & 22.836 & 13.690 & 1.880 & 12.844 & 1.906 \\
\hline Investment $($ Yes $=1)$ & 0.543 & 0.498 & 0.000 & 1.000 & 0.627 & 0.484 & 0.432 & 0.496 \\
\hline Network size & 31.962 & 35.900 & 0.000 & 717.000 & 35.260 & 41.449 & 27.585 & 26.198 \\
\hline Gender $($ Male $=1)$ & 0.669 & 0.471 & 0.000 & 1.000 & 0.663 & 0.473 & 0.678 & 0.467 \\
\hline Owner's age & 46.509 & 10.420 & 17.000 & 94.000 & 45.855 & 10.243 & 47.377 & 10.590 \\
\hline Education & 0.250 & 0.433 & 0.000 & 1.000 & 0.279 & 0.448 & 0.212 & 0.409 \\
\hline \multirow[t]{4}{*}{ Number of observations } & 6,075 & & & & 3,464 & & 2,611 & \\
\hline & [100] & & & & {$[57.02]$} & & [42.98] & \\
\hline & \multicolumn{2}{|c|}{$\begin{array}{l}\text { Full sample } \\
\text { (A) }\end{array}$} & \multicolumn{2}{|c|}{$\begin{array}{l}\text { UC firms } \\
\text { (B) }\end{array}$} & \multicolumn{2}{|l|}{$\begin{array}{l}\text { PC firms } \\
\text { (C) }\end{array}$} & \multicolumn{2}{|l|}{$\begin{array}{l}\text { FC firms } \\
\text { (D) }\end{array}$} \\
\hline & Mean & $\overline{\text { S.D. }}$ & Mea & S.D. & Mean & S.D. & Mean & S.D. \\
\hline Inf. cred. access $($ Yes $=1)$ & 0.570 & 0.495 & 0.47 & 0.499 & 0.660 & 0.474 & 0.661 & 0.473 \\
\hline Inf. cred. value (log.) & 3.670 & 5.198 & 2.63 & 4.566 & 4.383 & 5.682 & 4.878 & 5.483 \\
\hline Number of observations & \multicolumn{2}{|l|}{$\begin{array}{l}6,075 \\
{[100]}\end{array}$} & \multicolumn{2}{|c|}{$\begin{array}{c}3,006 \\
{[49.48]}\end{array}$} & \multicolumn{2}{|l|}{$\begin{array}{c}1,216 \\
{[20.02]}\end{array}$} & \multicolumn{2}{|l|}{$\begin{array}{c}1,853 \\
{[30.50]}\end{array}$} \\
\hline \multicolumn{3}{|l|}{ Mean of inf. cred. value } & \multicolumn{2}{|c|}{$\begin{array}{c}P C \text { vs. } U C \\
\text { (E) }\end{array}$} & \multicolumn{2}{|c|}{$\begin{array}{c}F C v s . U C \\
(\mathrm{~F})\end{array}$} & \multicolumn{2}{|l|}{$\begin{array}{c}F C \text { vs. } P C \\
(\mathrm{G})\end{array}$} \\
\hline Difference & & & \multicolumn{2}{|c|}{1.747} & \multicolumn{2}{|c|}{2.243} & \multicolumn{2}{|l|}{0.495} \\
\hline$t$-stats & & & \multicolumn{2}{|c|}{$10.464 * * *$} & \multicolumn{2}{|c|}{$15.383 * * *$} & \multicolumn{2}{|l|}{$2.413 * * *$} \\
\hline Number of observations & & & 4,2 & & 4,859 & & 3,069 & \\
\hline
\end{tabular}

Notes: Percentages are in brackets. AIC and NAIC stand for access to informal credit and non-access to informal credit, respectively. UC, PC, and FC stand for unconstrained, partially constrained, and fully constrained, respectively. *** indicates significance at 1 percent. $t$-stats are reported from ttest with equal variances. The null hypothesis is $\mathrm{H}_{0}: \mathrm{Difference}_{<} 0$. 
Table VI. Credit constraints and the probability of informal credit access

\begin{tabular}{|c|c|c|c|c|c|c|}
\hline \multirow[t]{2}{*}{ Variables } & \multicolumn{3}{|c|}{$\begin{array}{l}\text { Correlated random-effects (CRE) } \\
\text { Probit }\end{array}$} & \multicolumn{3}{|c|}{ Random-effects (RE) Probit } \\
\hline & $\begin{array}{c}\text { Coef. } \\
{[1]} \\
\end{array}$ & $\begin{array}{l}\text { S.E. } \\
{[2]}\end{array}$ & $\begin{array}{c}\text { M.E. } \\
{[3]}\end{array}$ & $\begin{array}{c}\text { Coef. } \\
{[4]}\end{array}$ & $\begin{array}{l}\text { S.E. } \\
{[5]}\end{array}$ & $\begin{array}{c}\text { M.E. } \\
{[6]}\end{array}$ \\
\hline \multicolumn{7}{|l|}{ Credit constrained } \\
\hline PC vs. UC & $0.262 * * *$ & $(0.054)$ & $0.086^{* * *}$ & $0.319 * * *$ & $(0.052)$ & $0.106^{* * *}$ \\
\hline FC vs. UC & $0.417 * * *$ & $(0.048)$ & $0.135 * * *$ & $0.466^{* * *}$ & $(0.042)$ & $0.153 * * *$ \\
\hline Firm size (log.) & $-0.049 * *$ & $(0.023)$ & $-0.016 * *$ & -0.005 & $(0.016)$ & -0.002 \\
\hline Firm age & 0.0001 & $(0.003)$ & 0.000 & $-0.003 *$ & $(0.002)$ & $-0.001 *$ \\
\hline Firm type $($ Household $=1)$ & 0.039 & $(0.106)$ & 0.013 & $-0.180 * * *$ & $(0.054)$ & $-0.058 * * *$ \\
\hline Revenue (log.) & $0.075 * * *$ & $(0.016)$ & $0.024 * * *$ & $0.083 * * *$ & $(0.013)$ & $0.027 * * *$ \\
\hline Investment $($ Yes $=1)$ & $0.412 * * *$ & $(0.046)$ & $0.132 * * *$ & $0.499 * * *$ & $(0.040)$ & $0.161 * * *$ \\
\hline Network size & $0.001 *$ & $(0.001)$ & 0.000 & $0.002 * * *$ & $(0.001)$ & $0.001 * * *$ \\
\hline Gender $($ Male = 1$)$ & -0.070 & $(0.061)$ & -0.022 & 0.010 & $(0.041)$ & 0.003 \\
\hline Owner's age & 0.002 & $(0.003)$ & 0.001 & $-0.008 * * *$ & $(0.002)$ & $-0.003 * * *$ \\
\hline Education & $-0.236 * * *$ & $(0.058)$ & $-0.075 * * *$ & $-0.192 * * *$ & $(0.047)$ & $-0.062 * * *$ \\
\hline Constant & -0.446 & $(0.374)$ & & -0.284 & $(0.278)$ & \\
\hline Year effects & Yes & & Yes & Yes & & \\
\hline Location effects & Yes & & Yes & Yes & & \\
\hline Mundlak correction & Yes & & Yes & No & & \\
\hline Hausman Joint test & $55.03 * * *$ & & & $\ldots$ & & \\
\hline Pairwise comparisons & Contrast & S.E. & & Contrast & S.E. & \\
\hline FC vs. PC & $0.155 * * *$ & $(0.058)$ & & $0.147 * * *$ & $(0.057)$ & \\
\hline
\end{tabular}

Notes: Dependent variable is informal credit access. *, **, and *** indicate significance at 10 percent, 5 percent, and 1 percent, respectively. Standard errors are in parentheses. Marginal effects (M.E.) are reported in columns 3 and 6. UC, $\mathrm{PC}$, and FC stand for unconstrained, partially constrained, and fully constrained, respectively. Number of observations (clusters) is $6,075(1,215)$. 
Table VII. Credit constraints and informal credit value

\begin{tabular}{|c|c|c|c|c|c|c|}
\hline \multirow[t]{2}{*}{ Variables } & \multicolumn{3}{|c|}{$\begin{array}{l}\text { Correlated random-effects (CRE) } \\
\text { Tobit }\end{array}$} & \multicolumn{3}{|c|}{ Random-effects (RE) Tobit } \\
\hline & $\begin{array}{c}\text { Coef. } \\
{[1]} \\
\end{array}$ & $\begin{array}{l}\text { S.E. } \\
{[2]}\end{array}$ & $\begin{array}{c}\text { M.E. } \\
{[3]}\end{array}$ & $\begin{array}{c}\text { Coef. } \\
{[4]}\end{array}$ & $\begin{array}{r}\text { S.E. } \\
{[5]}\end{array}$ & $\begin{array}{c}\text { M.E. } \\
{[6]}\end{array}$ \\
\hline \multicolumn{7}{|l|}{ Credit constrained } \\
\hline PC vs. UC & 0.563 & $(0.501)$ & 0.197 & $1.138 * *$ & $(0.490)$ & $0.395^{* *}$ \\
\hline FC vs. UC & $3.690 * * *$ & $(0.461)$ & $1.475 * * *$ & $4.570 * * *$ & $(0.407)$ & $1.834 * * *$ \\
\hline Firm size (log.) & 0.123 & $(0.229)$ & 0.047 & $0.395 * *$ & $(0.155)$ & $0.151^{* *}$ \\
\hline Firm age & -0.013 & $(0.031)$ & -0.005 & -0.020 & $(0.020)$ & -0.008 \\
\hline Firm type $($ Household $=1)$ & 0.841 & $(1.025)$ & 0.321 & $-1.503 * * *$ & $(0.502)$ & $-0.574 * * *$ \\
\hline Revenue (log.) & $0.500 * * *$ & $(0.162)$ & $0.191 * * *$ & $0.605 * * *$ & $(0.135)$ & $0.231 * * *$ \\
\hline Investment $($ Yes $=1)$ & $4.112 * * *$ & $(0.452)$ & $1.572 * * *$ & $4.812 * * *$ & $(0.398)$ & $1.838 * * *$ \\
\hline Network size & $0.010^{*}$ & $(0.006)$ & $0.004 *$ & 0.008 & $(0.005)$ & 0.003 \\
\hline Gender $($ Male $=1)$ & -0.553 & $(0.586)$ & -0.212 & -0.087 & $(0.381)$ & -0.033 \\
\hline Owner's age & 0.014 & $(0.031)$ & 0.005 & $-0.045^{* *}$ & $(0.018)$ & $-0.017^{* *}$ \\
\hline Education & -0.605 & $(0.544)$ & -0.231 & -0.607 & $(0.447)$ & -0.232 \\
\hline Constant & $-15.215^{* * *}$ & $(3.387)$ & & $-12.797 * * *$ & $(2.618)$ & \\
\hline Year effects & Yes & & & Yes & & \\
\hline Location effects & Yes & & & Yes & & \\
\hline Mundlak correction & Yes & & & No & & \\
\hline Hausman Joint test & $37.04 * * *$ & & & $\cdots$ & & \\
\hline Pairwise comparisons & Contrast & S.E. & & Contrast & S.E. & \\
\hline FC vs. PC & $3.127 * * *$ & $(0.524)$ & & $3.432 * * *$ & $(0.510)$ & \\
\hline
\end{tabular}

Notes: Dependent variable is informal credit value. $*, * *$, and $* * *$ indicate significance at 10 percent, 5 percent, and 1 percent, respectively. Standard errors are in parentheses. Marginal effects (M.E.) are reported in columns 3 and 6. UC, PC, and FC stand for unconstrained, partially constrained, and fully constrained, respectively. Number of observations (clusters) is $6,075(1,215)$. 
Table VIII. Binary credit constraint and informal credit access

\begin{tabular}{|c|c|c|c|c|}
\hline \multirow[t]{3}{*}{ Variables } & \multicolumn{2}{|c|}{$\begin{array}{l}\text { Probability of informal credit } \\
\text { access }\end{array}$} & \multicolumn{2}{|c|}{ Value of informal credit } \\
\hline & CRE & $\mathrm{RE}$ & CRE & $\mathrm{RE}$ \\
\hline & (1) & (2) & (3) & (4) \\
\hline Credit constrained $(\mathrm{Yes}=1)$ & $\begin{array}{c}0.355^{* * *} \\
(0.041)\end{array}$ & $\begin{array}{c}0.415 * * * \\
(0.037)\end{array}$ & $\begin{array}{c}2.353 * * * \\
(0.404)\end{array}$ & $\begin{array}{c}3.363 * * * \\
(0.366)\end{array}$ \\
\hline Firm size (log.) & $\begin{array}{c}-0.051 * * \\
(0.023)\end{array}$ & $\begin{array}{l}-0.008 \\
(0.016)\end{array}$ & $\begin{array}{c}0.090 \\
(0.230)\end{array}$ & $\begin{array}{l}0.311^{* *} \\
(0.156)\end{array}$ \\
\hline Firm age & $\begin{array}{c}0.000 \\
(0.003)\end{array}$ & $\begin{array}{l}-0.003 * \\
(0.002)\end{array}$ & $\begin{array}{l}-0.012 \\
(0.031)\end{array}$ & $\begin{array}{l}-0.017 \\
(0.020)\end{array}$ \\
\hline Firm type $($ Household $=1)$ & $\begin{array}{c}0.040 \\
(0.106)\end{array}$ & $\begin{array}{c}0.175 * * * \\
(0.054)\end{array}$ & $\begin{array}{c}0.862 \\
(1.030)\end{array}$ & $\begin{array}{c}-1.405^{* * *} \\
(0.505)\end{array}$ \\
\hline Revenue (log.) & $\begin{array}{c}0.074 * * * \\
(0.016)\end{array}$ & $\begin{array}{c}0.081 * * * \\
(0.013)\end{array}$ & $\begin{array}{c}0.466 * * * \\
(0.162)\end{array}$ & $\begin{array}{c}0.539 * * * \\
(0.134)\end{array}$ \\
\hline Investment $($ Yes $=1)$ & $\begin{array}{c}0.399 * * * \\
(0.045)\end{array}$ & $\begin{array}{c}0.481 * * * \\
(0.040)\end{array}$ & $\begin{array}{c}3.851 * * * \\
(0.452)\end{array}$ & $\begin{array}{c}4.397 * * * \\
(0.394)\end{array}$ \\
\hline Network size & $\begin{array}{c}0.001 \\
(0.001)\end{array}$ & $\begin{array}{c}0.002 * * * \\
(0.001)\end{array}$ & $\begin{array}{l}0.011^{*} \\
(0.006)\end{array}$ & $\begin{array}{c}0.008 \\
(0.005)\end{array}$ \\
\hline Gender $($ Male $=1)$ & $\begin{array}{l}-0.069 \\
(0.061)\end{array}$ & $\begin{array}{c}0.013 \\
(0.041)\end{array}$ & $\begin{array}{l}-0.545 \\
(0.589)\end{array}$ & $\begin{array}{l}-0.008 \\
(0.383)\end{array}$ \\
\hline Owner's age & $\begin{array}{c}0.002 \\
(0.003)\end{array}$ & $\begin{array}{c}-0.008^{* * *} \\
(0.002)\end{array}$ & $\begin{array}{c}0.015 \\
(0.031)\end{array}$ & $\begin{array}{c}-0.043 * * \\
(0.018)\end{array}$ \\
\hline Education & $\begin{array}{l}-0.239 * * * \\
(0.058)\end{array}$ & $\begin{array}{l}-0.194 * * * \\
(0.047)\end{array}$ & $\begin{array}{l}-0.701 \\
(0.546)\end{array}$ & $\begin{array}{l}-0.685 \\
(0.450)\end{array}$ \\
\hline Constant & $\begin{array}{l}-0.392 \\
(0.373)\end{array}$ & $\begin{array}{l}-0.189 \\
(0.275)\end{array}$ & $\begin{array}{c}-14.156^{* * *} \\
(3.398)\end{array}$ & $\begin{array}{c}-10.241^{* * *} \\
(2.602)\end{array}$ \\
\hline Year effects & Yes & Yes & Yes & Yes \\
\hline Location effects & Yes & Yes & Yes & Yes \\
\hline Mundlak correction & Yes & No & Yes & No \\
\hline Hausman Joint test & $54.69 * * *$ & $\ldots$ & $46.85 * * *$ & $\ldots$ \\
\hline
\end{tabular}

Notes: $*{ }^{* *}$, and $* * *$ indicate significance at 10 percent, 5 percent, and 1 percent, respectively. Standard errors are in parentheses. Number of observations (clusters) is 6,075 $(1,215)$. 
Table A1. Number of enterprises interviewed in survey rounds

\begin{tabular}{cccccc}
\hline City/Province & 2005 & 2007 & 2009 & 2011 & 2013 \\
\hline Ha Noi & 310 & 296 & 299 & 293 & 284 \\
Phu Tho & 283 & 254 & 271 & 255 & 262 \\
Ha Tay & 398 & 394 & 384 & 350 & 345 \\
Hai Phong & 217 & 205 & 227 & 222 & 203 \\
Nghe An & 394 & 358 & 370 & 354 & 354 \\
Quang Nam & 177 & 173 & 167 & 166 & 167 \\
Khanh Hoa & 102 & 92 & 97 & 99 & 91 \\
Lam Dong & 94 & 89 & 76 & 84 & 88 \\
Ho Chi Minh City & 701 & 633 & 635 & 603 & 637 \\
Long An & 144 & 138 & 133 & 126 & 138 \\
Total & 2,820 & 2,632 & 2,659 & 2,552 & 2,569 \\
\hline
\end{tabular}

Source: Authors' calculations based on the Survey of Manufacturing SMEs in Vietnam

Table B1. Test of endogeneity: The two-stage approach

\begin{tabular}{|c|c|c|c|c|}
\hline \multirow[t]{2}{*}{ Variables } & \multicolumn{2}{|c|}{ Credit constraints (1) } & \multicolumn{2}{|c|}{ Access to informal credit (2) } \\
\hline & $\mathrm{PC}$ & $\mathrm{FC}$ & $\mathrm{PC}$ & $\mathrm{FC}$ \\
\hline Certificate of Land Use & $-0.147 * * *$ & $-0.077^{*}$ & & \\
\hline Right $($ Yes $=1)$ & $(0.055)$ & $(0.042)$ & & \\
\hline PC firms & & & $\begin{array}{c}0.470 * * * \\
(0.090)\end{array}$ & \\
\hline $\mathrm{PC}$ residuals & & & $\begin{array}{l}-0.055 \\
(0.036)\end{array}$ & \\
\hline FC firms & & & & $\begin{array}{c}0.556^{* * *} \\
(0.115)\end{array}$ \\
\hline FC residuals & & & & $\begin{array}{l}-0.052 \\
(0.066)\end{array}$ \\
\hline Firm characteristics & Yes & Yes & Yes & Yes \\
\hline Owner characteristics & Yes & Yes & Yes & Yes \\
\hline Year effects & Yes & Yes & Yes & Yes \\
\hline Location effects & Yes & Yes & Yes & Yes \\
\hline Number of observations & 4,222 & 4,859 & 4,222 & 4,859 \\
\hline Durbin-Wu-Hausman test & & & 2.430 & 0.630 \\
\hline of endogeneity $\chi^{2}$ & & & [0.119] & [0.429] \\
\hline
\end{tabular}

Notes: ${ }^{*}, * *$, and ${ }^{* *}$ indicate significance at 10 percent, 5 percent, and 1 percent, respectively. Standard errors are in parentheses. $P$-values are in brackets. PC and FC stand for partially constrained and fully constrained, respectively. Firm characteristics include firm size $(\log$.$) , firm age, firm type (Household =1)$, revenue $(\log$.$) ,$ investment, and network size. Owner characteristics include gender, age, and education. $\chi^{2}$ statistics are reported from Hausman test with the null hypothesis $\mathrm{H}_{0}$ : Credit constraint is not endogenous. Only main results are reported for the sake of brevity. 